\title{
The Concept of Essence of Fundamental Rights in the EU Legal Order: Peeling the Onion to its Core
}

\author{
Maja Brkan*
}

Essence of fundamental rights - Article 52(1) of the Charter - Multi-level protection of fundamental rights in Europe - Sources of essence - European Court of Justice case law on 'very substance' of fundamental rights Constitutional traditions common to the Member States - European Court of Human Rights - Court of Justice of the EU - Schrems - Principle of proportionality - Absolute theory - Relative theory - Classification of interferences with essence - Objective interference - Subjective interference Absolute rights - EU methodology for determination of interference with essence

\section{INTRODUCTION}

Establishing an interference with a fundamental right in EU law can be compared to peeling an onion: the outer layer is the fundamental right as a whole, without its value being diminished in any way; the next layer comprises a justified interference with this right, ${ }^{1}$ followed by an unjustified interference. ${ }^{2}$ Even closer to the inside of the onion is a particularly serious interference with

*Assistant Professor, Faculty of Law, Maastricht University. The author would like to thank Bartosz Marciniak, Giovanni Sartor, Marijn van der Sluis, Christoph Sobotta and Bruno de Witte for discussions and comments on an earlier draft of this paper; Mirjam Abner, Matej Accetto, Andrei Florea, Martin Husovec, Jan Komárek, Bartosz Marciniak and Alicja Sikora for helping the author with commentaries of national constitutional provisions; and the anonymous reviewers for their valuable suggestions for the improvement of this article during the review process. The usual disclaimer applies.

${ }^{1}$ See, for example, ECJ Case C-291/12, Schwarz, ECLI:EU:C:2013:670, paras 31-64; in para. 64 the ECJ concludes that interference with the fundamental rights to privacy and personal data arising from the requirement that a biometric passport contain the fingerprints of the passport holder, is justified by the 'aim of protecting against the fraudulent use of passports'.

${ }^{2}$ See, for example, ECJ Case C-92/09, Volker und Markus Schecke and Eifert, ECLI:EU: C:2010:662, paras 65-89. 
a fundamental right. ${ }^{3}$ Finally, the heart of the onion constitutes the core - or the essence (contenu essentiel, Wesensgehalt, wezenlijke inhoud, contenido esencial, conteúdo essencial, bistvena vsebina, podstata) - of a fundamental right. ${ }^{4}$ It seems necessary to unravel all previous layers in order to touch upon the essence of a fundamental right. The essence - sometimes referred to as the minimum, ${ }^{5}$ essential $^{6}$ or absolute $^{7}$ core of a right - represents the untouchable core or inner circle of a fundamental right that cannot be diminished, restricted or interfered with. An interference with the essence of a fundamental right makes the right lose its value for society and, consequently, for the right holders. At first glance, it might be easy to imagine such an inner circle of a fundamental right that should under no circumstances be affected. However, a closer look into the concept reveals its complexity, ranging from difficulties in its definition, including the lack of appropriate tools for such a definition and difficulties of delimitation between an interference with the essence of fundamental right and the unjustified ordinary or particularly serious interference with this right.

The notion of essence appears not only in the Charter of Fundamental Rights of the EU (Charter), but also in the constitutions of several EU Member States ${ }^{8}$ and third countries, ${ }^{9}$ as part of general clauses regulating restrictions of fundamental rights. Moreover, the early case law of the European Court of Justice required safeguarding the 'substance' of fundamental rights ${ }^{10}-$ a notion which was later converted into 'essence' in the text of the Charter. Furthermore, as explained below, even though the European Convention on Human Rights

${ }^{3}$ For an example of an unjustified particularly serious interference with the fundamental right to privacy see ECJ Joined Cases C-293/12 and C-594/12, Digital Rights Ireland, ECLI:EU: C:2014:238, paras 37, 39.

${ }^{4}$ See, for example, ECJ Case C-362/14, Schrems, ECLI:EU:C:2015:650, para. 94, 95.

${ }^{5}$ K.G. Young, 'The Minimum Core of Economic and Social Rights: A Concept in Search of Content', 33 Yale Journal of International Law (2008) p. 113; K. Lehmann, 'In Defense of the Constitutional Court: Litigating Socio-Economic Rights and the Myth of the Minimum Core', 22 American University International Law Review (2006-2007) p. 163; D. Bilchitz, 'Towards a Reasonable Approach to the Minimum Core: Laying the Foundations for Future Socioeconomic Rights Jurisprudence', 19 South African Journal on Human Rights (2003) p. 1.

'J. Rivers, 'Proportionality and Variable Intensity of Review', 65(1) The Cambridge Law Journal (2006) p. 180.

${ }^{7}$ Rivers, supra n. 6, p. 184.

${ }^{8}$ See the constitutions of Estonia (Art. 17(2)), Germany (Art. 19(2)), Hungary (Art. I(3)), Poland (Art. 31(3)), Portugal (Art. 18), Romania (Art. 53(2)), Slovakia (Art. 13(4)), Spain (Art. 53(1)).

${ }^{9}$ For example, Turkey (Art. 13), Argentina (Art. 28), Namibia (Art. 22(a)), Switzerland (Art. 36). The South African Constitution contains a concept of 'minimum core'; in theory see Lehmann, supra n. 5.

${ }^{10}$ See ECJ Case 4/73, Nold, Kohlen- und Baustoffgroßhandlung v Commission ECLI:EU: C:1974:51, para. 14; ECJ Case C-44/79, Hauer v Land Rheinland-Pfalz, ECLI:EU:C:1979:290, paras 23, 30; ECJ Case 265/87, Schräder v Hauptzollamt Gronau, ECLI:EU:C:1989:303, para. 15. 
(ECHR) does not contain an explicit reference to the notion of essence, the idea of essence is present in the prohibition against the abuse of rights and in the abundant case law of the European Court of Human Rights ${ }^{11}$ referring to this concept. The essence of fundamental rights is also (implicitly) protected in the International Covenant on Civil and Political Rights, ${ }^{12}$ which has been subject to contentious interpretation. ${ }^{13}$ To separate the interference with the essence from an ordinary (or serious) interference with a fundamental right, the former has sometimes been described as an 'extreme infringement ${ }^{14}$ of a fundamental right.

From the beginning of the drafting of the Charter, there was consensus in the Convention to include the concept of essence in its text, ${ }^{15}$ although many delegates were uncertain as to the meaning of this notion, ${ }^{16}$ presumably those who were not familiar with it from their national constitutional orders. It seems that this uncertainty led to this notion being changed several times. Initially, the wording required the limitations of rights not to infringe 'the essential content (contenu essentiel) of the rights in question', ${ }^{17}$ which was later modified into the requirement to respect the 'actual substance (substance même) of those rights and freedoms' ${ }^{18}$ For a short while the concept disappeared from the text of the Charter, ${ }^{19}$ but it was eventually inserted back into its text. According to the final

${ }^{11}$ ECtHR 28 May 1985, Case No. 8225/78, Ashingdane v United Kingdom, paras 57, 59; ECtHR 27 August 1991, Case Nos. 12750/87, 13780/88, 14003/88, Philis v Greece, paras 59, 65; ECtHR 23 June 2016, Case No. 20261/12, Baka v Hungary, para. 121; ECtHR 21 June 2016, Case No. 5809/08, Al-Dulimi and Montana Management Inc. v Switzerland, para. 151; ECtHR 21 December 2000, Case No. 34720/97, Heaney and McGuinness v Ireland, paras 55, 58; ECtHR 11 July 2002, Case No. 28957/95, Christine Goodwin v United Kingdom, paras 99-101.

${ }^{12}$ The text of the Covenant does not specifically refer to the notion of 'essence', but this notion came into existence through the interpretation of Covenant's Art. 5(1) prohibiting - similarly to the ECHR - destruction of rights and their limitation to a greater extent than provided by Covenant. See J. Von Bernstorff, 'Kerngehaltsschutz durch den UN-Menschenrechtsausschuss und den EGMR: Vom Wert kategorialer Argumentationsformen', 50 Der Staat (2011) p. 170; M. Nowak, U.N. Covenant on Civil and Political Rights: CCPR Commentary, 2nd edn. (Engel 2005) p. 115.

${ }^{13}$ H. Hofmann, 'Art. 19', in B. Schmidt-Bleibtreu and F. Klein, Kommentar zum Grundgesetz (Luchterhand 2004) p. 613.

${ }^{14}$ Rivers, supra n. 6, p. 184.

${ }^{15}$ M. Borowsky, 'Artikel 52 Tragweite und Auslegung der Rechte und Grundsätze', in Meyer (ed.), Charta der Grundrechte der Europäischen Union (Nomos 2011), p. 670; R. Grote and T. Marauhn, EMRK/GG: Konkordanzkommentar zum europäischen und deutschen Grundrechtsschutz (Mohr Siebeck 2006) p. 370.

${ }^{16}$ Meyer, supra n. 15, p. 681.

${ }^{17}$ Article Y (Limitations) of Draft Charter of Fundamental Rights of the European Union, CHARTE 4123/1/00 REV 1, 15 February 2000. Emphasis added.

${ }^{18}$ Art. 47 (Limitation of guaranteed rights) of Draft Charter of Fundamental Rights of the European Union, CHARTE 4316/00, 16 May 2000. Emphasis added.

${ }^{19}$ Art. 50 (Scope of guaranteed rights) of Draft Charter of Fundamental Rights of the European Union, CHARTE 4422/00, 28 July 2000. 
version of Article 52(1) of the Charter, '[a]ny limitation on the exercise of the rights and freedoms recognised by this Charter must be provided for by law and respect the essence of those rights and freedoms. ${ }^{20}$

The overarching goal of this paper is to provide an in-depth analysis of the notion of essence of fundamental rights and, more specifically, to address the question of the content and particularities of this notion within the EU legal order, as well as to establish an EU methodology for determining when an interference with the essence takes place. The more detailed structure of this article is therefore as follows. First, the article deals with the preliminary question of an independent value of this notion, closely linked to the relationship between the concept of essence and the concept of proportionality. Furthermore, in order to consider the notion of essence from a broader perspective, the article explores the constitutional origins of essence at both the national and the European level. Such an approach is necessary in order to understand the first conceptualisations of essence at the level of national constitutions and the gradual constitutional cross-fertilisation with other legal orders, both national and European. This analysis is followed by a discussion on how to conceptualise the notion of essence and how to establish the constitutive elements of this concept. Drawing upon these constitutive elements, the article finally suggests an EU approach to establishing an interference with essence. ${ }^{21}$

\section{The INDEPendent VALue of ESSENCE}

Before embarking upon an analysis of the concept of essence, it is necessary to examine the question of whether this notion should be ascribed a practical or merely a declaratory value and, notably, how the relationship between essence and proportionality should be approached. Even though the relationship between the principle of proportionality and the concept of essence might, at a first glance, seem straightforward as they can be seen as mutually exclusive, actual practice shows that it is a rather complex endeavour to assign the concept of essence an appropriate place within (or outside) proportionality.

The constitutional doctrine is divided regarding the question of whether essence should be recognised as an independent concept which cannot be subject to proportionality balancing, or whether all breaches of fundamental rights that cannot be justified can be viewed as disproportional, that is to say, in terms of proportionality and disproportionality. These divergent positions on the correlation between essence

\footnotetext{
${ }^{20}$ Emphasis added.

${ }^{21}$ Differently from existing doctrine on the matter of 'essence', the present article analyses the notion of 'essence' from the perspective of Art. 52(1) of the Charter itself, its characteristics, constitutive traits and difficulties related to its conceptualisation. CfA. Von Bogdandy et al., 'Reverse Solange-Protecting the essence of fundamental rights against EU Member States', 49 Common Market Law Review (2012) p. 489.
} 
and proportionality are epitomised in the relative theory and the absolute theory, which have their origins in German doctrine. Pursuant to the relative theory, the notion of essence should have merely a declaratory nature as all interferences with fundamental rights can be assessed through the principle of proportionality and can hence be potentially justified. ${ }^{22}$ Alexy, a supporter of the relative theory, challenges the independent value of the notion of essence by concluding that the 'guarantee of an essential core ... does not contain any further control on the limitability of constitutional rights beyond that already contained in the principle of proportionality.' ${ }^{23}$ Rivers claims that the 'instances of a denial of rights that could never conceivably be justified' can indeed be imagined, but they can just as well be considered as a disproportionate interference. ${ }^{24}$ Barak equally argues that the core is best understood in terms of proportionality ${ }^{25}$ and Van der Schyff claims that the absolute theory is in fact a relative theory disguised as absolute. ${ }^{26}$

To the contrary, the proponents of absolute theory build upon a premise that the core of a right can under no circumstances be limited, meaning that the overriding reasons that could potentially justify such interference do not exist, so the principle of proportionality does not apply. ${ }^{27}$ The absolute theory distinguishes between two parts of every fundamental right: a nucleus, being the essence of this right, and a peripheral part of a fundamental right. ${ }^{28}$ The advocates of this theory can be found mostly in the German doctrine; Leisner, for example, points out that defining the absolute core of rights through proportionality would jeopardise the inherent absoluteness of the core concept. ${ }^{29}$ Schaks bases himself on the argument of systematic interpretation and asserts that following a relative theory would strip the constitutional provision guaranteeing the protection of essence of its independent scope of application. Papier analyses the notion of essence in the framework of the right to property and points out that the essence has to be construed as an independent safeguard in fundamental rights protection. $^{30}$ Moreover, certain Spanish authors are equally in favour of

${ }^{22}$ R. Alexy, A Theory of Constitutional Rights (Oxford 2004) p. 193.

${ }^{23}$ Alexy, supra n. 22, p. 196.

${ }^{24}$ Rivers, supra n. 6, p. 187.

${ }^{25}$ A. Barak, Proportionality: Constitutional Rights and their Limitations (Cambridge University Press 2016) p. 498.

${ }^{26}$ G. Van der Schyff, 'Cutting to the Core of Conflicting Rights: The Question of Inalienable Cores in Comparative Perspective', in E. Brems (ed.), Conflicts Between Fundamental Rights (Intersentia 2008) p. 135.

${ }^{27}$ Alexy, supra n. 22, p. 193, 195.

${ }^{28}$ J. Jiménez Campo, Derechos fundamentales: conceptos y garantías (Trotta 1999) p. 22.

${ }^{29}$ W. Leisner, Grundrechte und Privatrecht (Beck 1960) p. 155.

${ }^{30}$ Papier also points out that the essence of the right to property encompasses the private use of property and the free disposal of property; see H.-J. Papier, 'GG Art. 14', in T. Maunz and G. Dürig, Grundgesetz-Kommentar, 75. EL September 2015, available through Beck Online, point 333. 
absolute theory. ${ }^{31}$ Finally, Kokott rejects the relative theory and endorses the absolute theory from the comparative perspective at the intersection of different European constitutional orders. ${ }^{32}$

This article does not dispute the necessity of distinguishing the doctrine of the essence of fundamental rights from that of proportionality review, and hence advocates that the absolute theory should be followed in the EU legal order. The main reason for this argument is the circumstance that the notion of essence - and its predecessor 'very substance' - had, from early jurisprudence onwards, undeniable practical value in the case law of the European Court of Justice. As will be discussed more extensively below, the Court in its early pre-Charter jurisprudence ${ }^{33}$ required that a limitation of a fundamental right, in order to be justified, should not only be justified by a general (then) Community interest and be proportionate, but that it should also not impinge upon the substance of the fundamental right. ${ }^{34}$ Moreover, the European Court of Justice confirmed the practical value of this concept - also in its recent case law - using the notion of essence. While it is deplorable that this case law does not feature an explanation of the concept's meaning and importance, interest in this concept has increased since the judgments in Digital Rights Ireland ${ }^{35}$ and, even more importantly, Schrems. ${ }^{36}$ Apart from Alemo-Herron, ${ }^{37}$ Schrems is the only case where the European Court of Justice recognised that there was an interference with the essence, more precisely, with both the essence of the fundamental right to privacy and of the fundamental right to effective judicial protection. Furthermore, in the judgments in Tele2 Sverige, ${ }^{38}$ Florescu, $^{39}$ and other cases ${ }^{40}$ the European Court of Justice referred to

${ }^{31}$ M.E. Casas Baamonde and M. Rodríguez-Piñero y Bravo-Ferrer, Comentarios a la Constitución Española (Kluwer 2008) p. 1168; Jiménez Campo, supra n. 28, p. 23-24; F.J. Bastida Freijedo et al., Teoría general de los derechos fundamentales en la Constitución Española de 1978 (Publicado en la editorial Tecnos Madrid 2004), available at <www.unioviedo.es/constitucional/miemb/pdf/librodf. PDF>, visited 24 March 2018, p. 122.

32 J. Kokott, 'Grundrechtliche Schranken und Schrankenschranken' in D. Merten and H.-J. Papier (eds.), Handbuch der Grundrechte in Deutschland und Europa (Müller 2004) p. 892.

${ }^{33}$ See ECJ Case 4/73, Nold, Koblen- und Baustoffroßßhandlung v Commission ECLI:EU:C:1974:51, para. 14; ECJ Case C-44/79, Hauer v Land Rheinland-Pfalz, ECLI:EU:C:1979:290, para. 23, 30; ECJ Case 265/87, Schräder v Hauptzollamt Gronau, ECLI:EU:C:1989:303, para. 15.

${ }^{34}$ For the three criteria created by the ECJ see L. Besselink, 'Entrapped by the Maximum Standard: On Fundamental Rights, Pluralism and Subsidiarity in the European Union', 35(3) Common Market Law Review (1998) p. 634.

${ }^{35}$ See Digital Rights Ireland, supra n. 3.

${ }^{36}$ Schrems, supra n. 4.

${ }^{37}$ ECJ Case C-426/11, Alemo-Herron and Others, ECLI:EU:C:2013:521.

${ }^{38}$ ECJ Case C-203/15, Tele2 Sverige, ECLI:EU:C:2016:970, para. 101.

${ }^{39}$ ECJ Case C-258/14, Florescu and Others, ECLI:EU:C:2017:448, para. 55.

${ }^{40}$ ECJ Case C-190/16, Fries, ECLI:EU:C:2017:513, para. 38; ECJ Case C-18/16, K., ECLI:EU: C:2017:680, para. 35; ECJ Case C-601/15 PPU, J. N., ECLI:EU:C:2016:84, para. 52; ECJ Case 
this concept, albeit it did not find an interference with the essence. The Court's case law is therefore an important trigger that enlivens the discussion on a broader constitutional issue: what is the 'essence' of a fundamental right?

\section{THE SOURCES OF 'ESSENCE' IN A MULTI-LEVEL FUNDAMENTAL RIGHTS SYSTEM}

The protection of fundamental rights in Europe is embedded in a complex multi-level system, operating on the level of national constitutional law, EU law and the ECHR. As Fabbrini rightly points out, fundamental rights in Europe 'are conceived ... in a plurality of legal sources and a multiplicity of legal frameworks which intertwine and overlap'. ${ }^{41}$ Identifying the correct contours of the notion of essence is, from this pluralist fundamental rights perspective, impossible without taking into account the two other layers of fundamental rights protection: national constitutions and the ECHR. In this part of the article, the constitutional sources for the adoption of the concept of the 'essence' of fundamental rights into the Charter are discussed. In order to conceptualise this notion within the EU legal order, a prior understanding of its roots and the rationale behind it is necessary. Even though there may be no explicit common understanding as to the sources of the concept of 'essence' in the Charter, three developments contributed to codification of this notion in EU law: protection of essence constitutes a general principle stemming from constitutional traditions common to the Member States; the European Court of Justice had, in its pre-Charter case law, already used a similar notion of 'very substance'; and this notion could potentially be inspired by the ECHR and European Court of Human Rights' case law. Exploring the roots and rationale does not only have explanatory value, but also an interpretative one as these sources of essence should also determine its content and interpretation. Because the EU's use of essence derives from different sources, its meaning should largely, although not entirely, be determined through these sources. Admittedly, according to the settled case law of the European Court of Justice, unless a provision of EU law expressly refers to the law of the Member States for determination of its meaning and scope, it has to be given 'an autonomous and uniform interpretation'

C-201/15, Anonymi Geniki Etairia Tsimenton Iraklis (AGET Iraklis), ECLI:EU:C:2016:972, para. 84-88; ECJ Case C-547/14, Philip Morris Brands and Others, ECLI:EU:C:2016:325, para. 151; ECJ Case C-484/14, Mc Fadden, ECLI:EU:C:2016:689, paras 91, 92; ECJ Case C-477/14, Pillbox 38, ECLI:EU:C:2016:324, paras 161, 164; ECJ Case C-129/14 PPU, Spasic, ECLI:EU: C:2014:586, paras 58, 59; ECJ C-650/13, Delvigne, ECLI:EU:C:2015:648, para. 48; ECJ C-528/13, Léger ECLI:EU:C:2015:288, para. 54; ECJ C-291/12, Schwarz, ECLI:EU:C:2013:670, para. 39.

${ }^{41}$ F. Fabbrini, Fundamental Rights in Europe: Challenges and Transformations in Comparative Perspective (Oxford University Press 2014) p. 20. 
throughout the $\mathrm{EU}^{42}$ and this should be no different as regards the notion of essence. It is submitted that at least the general principles common to Member States and the earlier case law of the European Court of Justice, but potentially also the ECHR and the pertinent case law, nevertheless do have interpretative value for this concept. According to Article 6(3) TEU, fundamental rights (and, it should be added, notions relating to these fundamental rights), as they result from the constitutional traditions common to the Member States, constitute general principles of the Union's law. These fundamental rights, stemming from Member States' constitutional traditions, shall be, as required by Article 52(4) of the Charter, interpreted in harmony with those traditions. The interpretation of the concept of essence in EU law is evidently inspired also by the earlier European Court of Justice case law, as well as potentially by the ECHR and the European Court of Human Rights case law which serve as the benchmark for determination of scope and interpretation of Charter rights, as epitomised by Article 52(3) Charter.

\section{Essence of fundamental rights as a general principle common to Member States?}

In a multi-level fundamental rights system, the adoption of the concept of the essence of fundamental rights in constitutions of certain EU Member States and other countries is a salient example of constitutional cross-fertilisation. Even though the idea of constitutional cross-fertilisation has been mainly used by political scientists when referring to the phenomenon of courts from one country importing ideas from the highest courts of other countries, using them as persuasive authorities, ${ }^{43}$ this theory can also be used to encompass the influence of a constitutional text or doctrine from one country on one or more other countries.

Looking more closely into horizontal cross-fertilisation, it can be established that the initial source of the concept of essence comes from the German Constitution which, in its Article 19(2), stipulates that '[i]n no case may the essence [Wesensgehalt] of a basic right be affected'. ${ }^{44}$ The introduction of the notion of

\footnotetext{
${ }^{42}$ See, for example, ECJ Case 327/82, Ekro EU:C:1984:11, para. 11; ECJ Case C-436/04, van Esbroeck, EU:C:2006:165, para. 35; ECJ Case C-261/09, Mantello, EU:C:2010:683, para. 38; ECJ Case C-60/12, Baláž, EU:C:2013:733, para. 26; Spasic, supra n. 40, para. 79; ECJ Case C-511/14, Pebros Servizi, EU:C:2016:448, para. 36; ECJ Case C-395/15, Daouidi, ECLI:EU:C:2016:917, para. 50.

${ }^{43}$ A.M. Slaughter, A New World Order (Princeton 2004) p. 70; A.M. Slaughter, 'Judicial Globalization', 40 Virginia Journal of International Law (2000) p. $1104 \mathrm{ff}$.

${ }^{44}$ For the English version of the German Constitution, see 'Basic Law for the Federal Republic of Germany', available at <www.bundesregierung.de/Content/EN/StatischeSeiten/breg/basic-lawcontent-list.html>, visited 20 April 2018.
} 
essence into the German Constitution aimed to prevent future Nazi-type violations of fundamental rights. ${ }^{45}$ The primary aim of the protection of essence is thus to prevent the application of fundamental rights in a way that would lead to the hollowing out (Aushöhlung) of fundamental rights. ${ }^{46}$ The German doctrine points out that the observance of essence binds primarily the ordinary legislature and secondarily also other authorities and courts $^{47}$ which could, when applying fundamental rights, strip the fundamental right from all substantive meaning. ${ }^{48}$ While the adoption of this notion in the German Constitution initially did not trigger much discussion on its scope of application, Remmert points out that there is a vigorous debate in the German doctrine as to the exact meaning of this notion. ${ }^{49}$ In particular, the doctrine remains divided on the question of whether the notion of essence should be given an independent value as an untouchable core of fundamental rights (absolute theory) or whether the guarantees offered by the essence should be reduced to the principle of proportionality (relative theory). ${ }^{50}$ Even though some of the decisions of the German Federal Constitutional Court endorse a relative approach, the majority of its decisions follow the absolute approach. ${ }^{51}$ The Constitutional Court's preference for the latter can be illustrated with a case in which the essence of the right to personal freedom was interfered with due to the fact that a person with mental health issues was placed in a host family in order to have a more structured life and to get used to regular work. ${ }^{52}$ The Court pointed out that the freedom of an individual can be restricted only for the purpose of protection of society or the protection of the person himself, but not for the purpose of 'improving' the person, as this is not a function of a state. ${ }^{53}$

From the German Constitution, the idea of essence was gradually exported into the texts of the constitutions of certain other EU Member States ${ }^{54}$ and third countries. $^{55}$ The origins of the concept of essence coincide with the first

${ }^{45}$ B. Remmert, 'GG Art. 19', in T. Maunz and G. Dürig (eds.), Grundgesetz-Kommentar, 78. EL September 2016, available through Beck Online, points 4-5; C. Grabenwarter and T. Marauhn, 'Grundrechtseingriff und -schranken' in Grote and Marauhn, supra n. 15, p. 369.

${ }^{46}$ Remmert, supra n. 45, point 1.

${ }^{47}$ C. Enders, 'GG Art. 19', in V. Epping and C. Hillgruber (eds.), BeckOK Grundgesetz, 32. ed., available through Beck Online, point 24-25.

${ }^{48}$ Grabenwarter and Marauhn, supra n. 45 , p. 369.

${ }^{49}$ Remmert, supra n. 45, points 1 and 10.

${ }^{50}$ Grabenwarter and Marauhn, supra n. 45 , p. 369.

${ }^{51}$ Alexy, supra n. 22, p. 193-194.

${ }^{52}$ BVerfG: Durchführung des Sozialstaatsprinzips in Verfahren des JWG und BSHG, Neue Juristische Wochenschrift 1967, p. 1795.

${ }^{53}$ Ibid., p. 1800.

${ }^{54}$ Von Bernstorff, supra n. 12, p. 171; Von Bogdandy et al., supra n. 21, p. 510.

${ }^{55}$ For example, Turkey (Art. 13), Argentina (Art. 28), Namibia (Art. 22(a)), Switzerland (Art. 36). 
codifications of fundamental rights in Europe, even before the existence of the EU (or EEC). ${ }^{56}$ Even though in Germany the constitutional doctrine interpreting this notion does not agree on whether it should be ascribed much practical value, ${ }^{57}$ the notion of essence is nevertheless somewhat humorously described as the most successful export good of the 1949 Constitution. ${ }^{58}$ The initial goal of the prohibition on impairing the essence of a right - preventing a repeat of the atrocities of the Second World War was gradually surpassed by its reception into other constitutional texts which partially took over the concept and its theoretical background almost unchanged and partially developed further or moderately modified the idea.

Amongst the legal orders that closely follow the German tradition are the Spanish and Portuguese constitutional orders which both protect the 'essential content' (contenido esencial, ${ }^{59}$ conteúdo essencial ${ }^{60}$ ) of fundamental rights. The constitutional doctrine of both legal orders discusses the above-mentioned absolute and relative theories with regard to essence. While the leading commentary on the Portuguese Constitution shows awareness of absolute and relative theory with regard to the essence of fundamental rights, staying rather neutral on this point, ${ }^{61}$ the Spanish doctrine prefers the absolute theory over the relative theory of the contenido esencial; as a result, the notion of essence provides for an absolute protection against an interference which can never be justified. ${ }^{62}$ The Spanish Constitutional Court recognised the practical value of contenido esencial in a judgment giving rights to immigrants equal to those held by nationals. ${ }^{63}$ This judgment bears importance because the Spanish Constitutional Court construed the essence of fundamental rights as a brake on or limitation to the 'democratic freedom' of the legislature. ${ }^{64}$ Another important judgment of the

${ }^{56}$ On first codifications of fundamental rights in Europe see Fabbrini, supra n. 41, p. 7.

${ }^{57}$ Hofmann, supra n. 13, p. 742.

${ }^{58} \mathrm{P}$. Häberle, 'Wechselwirkungen zwischen deutschen und ausländischen Verfassungen', para. 41, as cited in Kokott, supra n. 32, p. 887.

${ }^{59}$ See Art. 53(1) of the Spanish Constitution.

${ }^{60}$ See Art. 18 of the Portuguese Constitution.

${ }^{61}$ J.J. Gomes Canotilho and V. Moreira, Constituição da República Portuguesa Anotada. Volume I, 4th edn (Coimbra Editora 2007) p. 395.

${ }^{62}$ Casas Baamonde and Rodríguez-Piñero y Bravo-Ferrer, supra n. 31, p. 1168; Jiménez Campo, supra n. 28, p. 23-24; Bastida et al., supra n. 31, p. 122. For a more sceptical position, compare C. Viera Álvarez, 'El contenido esencial de los derechos fundamentales: La libre iniciativa económica en España y Chile', 62 Revista de Ciencias Sociales (2013) p. 182.

${ }^{63}$ Judgment of the Spanish Constitutional Court No 236/2007, 7 November 2007. For a commentary see F. Balaguer Callejón, 'El contenido esencial de los derechos constitucionales y el régimen jurídico de la inmigración. Un comentario a la STC 236/2007 de 7 de noviembre', available at <www. ugr.es/ redce/REDCE10/articulos/15FranciscoBalaguerCallejon.htm>, visited 24 March 2018.

${ }^{64}$ M. del Camino Vidal Fueyo, 'La jurisprudencia del Tribunal Constitucional en materia de derechos fundamentales de los extranjeros a la lux de la STC 236/2007', 85 Revista Española de Derecho Constitucional (2009) p. 369. 
Spanish Constitutional Court was rendered in the case 11/1981 where this court interpreted the notion of essence in the context of the fundamental right to strike. ${ }^{65}$

Furthermore, in the case law of the Portuguese Constitutional Court, judgments can be identified in which the parties or the Court invoke the notion of conteúdo essencial, but the Court does not find an interference with this 'essential content', ${ }^{66}$ for example in the case $604 / 2008 .{ }^{67}$ In this case, the applicant challenged a previous decision by the Court of Appeal of Coimbra, claiming that the provision of the Portuguese Road Code enabling the imposition of sanctions for road offences interfered with the essence of the constitutional provision guaranteeing safeguards in criminal procedure (Article 32). ${ }^{68}$ The Portuguese Constitutional Court deemed the appeal inadmissible, not addressing the issue of essential content. ${ }^{69}$ In case 460/2011, when replying to an argument that the provision of national law limiting trial by jury to certain proceedings interfered with the essence of the fundamental right to a !trial, the Court, even though it did not find an interference with the essential content of this right, pointed out that the essential core of the right to a fair trial requires that the parties have equality of arms and effective means to safeguard their rights and that the legislature cannot create obstacles which arbitrarily or disproportionately hamper or impede access to the courts and effective judicial protection. ${ }^{70}$ Furthermore, in case 254/99 the Portuguese Constitutional Court stressed that the concept of essential content does not refer to the content of fundamental rights prima facie, but is a result of interpretation of fundamental rights. ${ }^{71}$ Even though the Constitutional Court in its jurisprudence does not expressly confirm the absolute theory, its preference for acknowledging the practical value of this concept could be read into these judgments.

In comparison, the relative theory, which permits balancing the essence of a right and other interests and thus brings the concept of essence within the framework of proportionality, ${ }^{72}$ is accepted in the Austrian legal order whereby the notion of essence was recognised through the case law of the

${ }^{65}$ Judgment of the Spanish Constitutional Court No. 11/1981, 8 April 1981. For a commentary see L. Parejo Alfonso, 'El contenido esencial de los derechos fundamentales en la jurisprudencia constitucional: a propósito de la sentencia del Tribunal Constitucional de 8 de abril de 1981', 3 Revista Española de Derecho Constitucional (1981) p. 169-190.

${ }^{66}$ The search was performed on the website of the Portuguese Constitutional Court (www. tribunalconstitucional.pt) with search terms 'artigo $18 .^{\circ}, \mathrm{n}^{\circ} 3^{\prime}$ ' as this is the provision of the Portuguese Constitution that contains the notion 'conteúdo essencial.

${ }^{67}$ Judgment of the Portuguese Constitutional Court No. 604/2008, 10 December 2008.

${ }^{68}$ Ibid., point 1.1 .

${ }^{69}$ Ibid., title III - Conclusions.

${ }^{70}$ Judgment of the Portuguese Constitutional Court No. 460/2011, 11 October 2011, point 2.4.

${ }^{71}$ Judgment of the Portuguese Constitutional Court No. 254/99, 4 May 1999, point 11.

${ }^{72}$ M. Sachs, Grundgesetz: Kommentar (Beck 2009) p. 743. 
Constitutional Court. ${ }^{73}$ Similarly, the Hungarian Constitution $^{74}$ and the Hungarian Constitutional Court, ${ }^{75}$ having adopted the notion of essential content ${ }^{76}$ proceed from a relative rather than an absolute understanding of this notion. ${ }^{77}$ It should be noted that the controversial Hungarian constitutional amendments in $2013{ }^{78}$ which were partially challenged before the European Court of Justice, ${ }^{79}$ did not change the constitutional provision guaranteeing the 'essential content' of fundamental rights. As we will see later in this article, the absolute and relative theories, developed in national constitutional traditions, have a normative value in determining how the notion of essence should be conceptualised.

Moreover, irrespective of different theories, in Poland the practice of the Constitutional Court uses the provision of the Polish Constitution relating to 'essence' (istota) ${ }^{80}$ in its case law. ${ }^{81}$ The Slovak Constitution equally protects the essence (podstata). ${ }^{82}$ Even though the provision of the Romanian Constitution regulating restrictions on the exercise of certain rights and freedoms dictates that the measure restricting a right should refrain from infringing the existence

\footnotetext{
${ }^{73}$ Kokott, supra n. 32, p. 891.

${ }^{74}$ After the fall of the communist regime, Hungary adopted a new constitution only in 2011; for text see <www.kormany.hu/download/e/02/00000/The\%20New\%20Fundamental\%20Law\%20of \%20Hungary.pdf $>$, visited 24 March 2018, which was amended with rather controversial amendments in 2013; for text see <www.mfa.gov.hu/NR/rdonlyres/8204FB28-BF22-481A-9426D2761D10EC7C/0/FUNDAMENTALLAWOFHUNGARYmostrecentversion01102013.pdf>, visited 24 March 2018.

${ }^{75}$ In the context of the interpretation of the concept of 'essential content', the Hungarian Constitutional Court, deciding on a case concerning the right to have one's own name, even went as far as to define the entirety of the right as an essential content and thereby to declare this right absolute. See Decision 58/2001 (XII. 7.) AB, in A. Holló and A. Erdei, Selected Decisions of the Constitutional Court of Hungary (1998-2001) (Akadémiai Kiadó 2005) p. 417-418.

${ }^{76}$ According to Art. I(3) of the Hungarian constitution, '[a] fundamental right may only be restricted to allow the effective use of another fundamental right or to protect a constitutional value, to the extent absolutely necessary, proportionate to the objective pursued and with full respect for the essential content of such fundamental right.'

${ }^{77}$ H. Küpper, Die ungarische Verfassung nach zwei Jahrzehnten des Übergangs (Peter Lang 2007) p. 92.

${ }^{78}$ See, in media, for example BBC: 'Q\&A: Hungary's controversial constitutional changes' <www.bbc.com/news/world-europe-21748878>, visited 24 March 2018.

${ }^{79}$ ECJ Case C-286/12, Commission v Hungary, ECLI:EU:C:2012:687. For a commentary see A. Vincze, 'The ECJ as the Guardian of the Hungarian Constitution: Case C-286/12 Commission v Hungary', 19 European Public Law (2013) p. 489-500.

${ }^{80}$ Art. 31(3) of the Polish Constitution.

${ }^{81}$ Judgment of Polish Constitutional Court of 12 January 2000, as cited in ECtHR 19 June 2006, Case No. 35014/97, Hutten-Czapska v Poland.

${ }^{82}$ See Art. 13(4) of the Slovak Constitution. In theory see J. Drgonec, Ústava Slovenskej Republiky: Komentár, 3rd edn. (Heuréka 2012) p. 291.
} 
(existenţei) - and not the essence (substanţa) - of such a right or freedom, ${ }^{83}$ it can be claimed that curtailing the existence of a fundamental right is indeed a way of infringing upon the essence of a fundamental right. ${ }^{84}$

Noting these differences between the legal orders of various EU Member States, it should be discussed whether recognition of the notion of essence can be seen as resulting in commonality amongst the constitutional traditions of these states. In this regard, it should be pointed out that the threshold for traditions being 'common' does not necessarily imply agreement on the meaning of the notion in all EU Member States. For example, in the $A M \& S$ case the European Court of Justice recognised the confidentiality of correspondence between a lawyer and her client as a common constitutional tradition despite the fact that the scope and conditions for its application varied considerably among the Member States. ${ }^{85}$ Moreover, as Advocate General Kokott reasoned in Akzo Nobel, recognising a notion as stemming from common constitutional traditions is not necessarily subject to the precondition that the practice in question should constitute a tendency which is uniform or has clear majority support', but it 'depends rather on an evaluative comparison of the legal systems' that have to take into account 'the aims and tasks of the European Union [and] the special nature of [...] EU law'. ${ }^{86}$ In support for her reasoning, the Advocate General cites two examples from the case law. In Mangold ${ }^{87}$ and later in Kücükdeveci, ${ }^{88}$ the European Court of Justice recognised the principle of non-discrimination on grounds of age without providing clear reasoning that this principle is firmly anchored in the legal orders of the Member States. ${ }^{89}$ Furthermore, the (then) General Court equally recognised the right of access to a file in competition law proceedings despite a lack of uniform

${ }^{83}$ Art. 53(2) of the Romanian Constitution. The original Constitution of Romania of 1991 (Official Gazette of Romania, Part I, No. 233 of 21 November 1991) was revised in 2003 with the Law No. 429/2003 on the revision of the Constitution of Romania (Official Gazette of Romania, Part I, No. 758 of 29 October 2003. The initial article dealing with the existence of fundamental rights (Art. 49(2)) was renumbered, in the new version, into Art. 53(2). Available at <www.cdep.ro/ pls/dic/site.page?id=371>, visited 24 March 2018.

${ }^{84}$ Romanian constitutional doctrine points out that this provision needs to be read together with the provision prohibiting 'suppression of the citizens' fundamental rights and freedoms'. See I. Zlatescu, Constitutional Law in Romania (Kluwer 2012) p. 116 and Art. 152(2) of the Romanian Constitution.

${ }^{85}$ ECJ Case C-155/79, AM \& $S v$ Commission, ECLI:EU:C:1982:157, para. 19-20.

${ }^{86}$ Opinion of AG Kokott in ECJ Case C-550/07 P, Akzo Nobel Chemicals and Akcros Chemicals v Commission, ECLI:EU:C:2010:229, para. 94. Emphasis in original. See commentary on Art. 52 by S. Peers and S. Prechal in S. Peers et al. (ed.), The EU Charter of Fundamental Rights: A Commentary (Beck/Hart 2014) p. 1504.

${ }^{87}$ ECJ Case C-144/04, Mangold, ECLI:EU:C:2005:709, para. 75.

${ }^{88}$ ECJ Case C-555/07, Kücükdeveci, ECLI:EU:C:2010:21, para. 21.

${ }^{89}$ In Mangold (para 74), the ECJ relied on 'various international instruments and ... the constitutional traditions common to the Member States' (emphasis added), without explaining to what extent the principle of non-discrimination on grounds of age is truly common. 
recognition of this right in Member States. ${ }^{90}$ This of course cannot lead to the conclusion that any random right can be derived from Member States' constitutional traditions. Nevertheless, along the lines of this case law, it can be argued that the evaluative comparison demonstrates that the sheer inclusion of the notion of essence in several national constitutions indicates a certain degree of commonality between these national legal orders that cannot be denied by divergences in interpretation of this notion. Indeed, what is common to these constitutional traditions is the very recognition of the concept in several national constitutions and in the case law of the highest national courts. ${ }^{91}$ Therefore, it could be argued that essence can be recognised as a part of the constitutional traditions common to the Member States. Admittedly, difficulties might arise when it comes to the interpretation of essence from the Charter 'in harmony' with these traditions, as required by Article 52(4) of the Charter, given the divergence among the Member States as to the interpretation of this notion, notably on the relationship between essence and proportionality and the related question of whether the essence should be seen as an independent legal concept. These divergent interpretations might create uncertainties as to the interpretation of essence from the Charter. However, according to the Explanations to the Charter, the interpretation of such common notions should not follow the 'lowest common denominator', but rather offer a 'high standard of protection'. ${ }^{92}$ The Explanations also require that the harmonious interpretation should be 'adequate for the law of the Union'. ${ }^{33}$ This means that the interpretation should be derived from common constitutional traditions, but that a certain margin of flexibility exists as to which national interpretation bears the most weight and how strictly it needs to be followed. Bearing the national interpretations in mind, this article analyses the question of the appropriate interpretation of the Charter notion of essence below. Before that discussion, however, further sources of essence require analysis.

\section{The pre-Charter case law of the European Court of Justice as a source of essence}

Another source of 'essence' from Article 52(1) of the Charter is the concept of the very substance (substance même, Wesensgehalt, kern, esencia, essência, bistvo, podstata) of fundamental rights, developed in the pre-Charter case law of the European Court of Justice. ${ }^{94}$ Even though the Explanations to the Charter do not expressly state that

\footnotetext{
${ }^{90}$ AG Kokott in Akzo Nobel, para. 97.

${ }^{91}$ Since the analysis of the legal orders of the Member States is not exhaustive, it is not excluded that more Member States recognise this notion in their national legal orders.

${ }^{92}$ Pointed out by Peers and Prechal, supra n. 86, p. 1504-1505, who rely on the Explanations to the Charter.

${ }^{93}$ Ibid.

${ }^{94}$ For the use of this notion in ECJ case law and its link to Art. 52(1) of the Charter, see Explanation on Article 52 - Scope and interpretation of rights and principles, OJ 2007, C 303/32.
} 
the very substance is the source of the essence, it can be reasonably assumed that the former notion had an impact on the inclusion of the latter in the Charter text. The concept of the very substance of a fundamental right, embedded in the famous phrase spelling out the ways in which fundamental rights can be restricted, had seen its birth in the early case law of the European Court of Justice, ${ }^{95}$ prior to Karlsson to which the Explanations make reference, and prior to the adoption of the Charter. This early jurisprudence, marked by its reliance on fundamental rights as general principles and the absence of a (binding) legal document codifying pan-EU fundamental rights, demonstrates the desire on the part of the European Court of Justice to protect a core of relative rights, potentially subjected to restrictions.

For example, in Nold, the seminal case in which the European Court of Justice referred to the protection of the substance of the fundamental right, the applicant challenged the Commission decision changing the conditions for selling coal on the German market on the basis that this decision interfered with his fundamental right to property and freedom to pursue economic activity as protected by the German Constitution and international treaties. ${ }^{96}$ The European Court recognised these rights as being part of Community law and stressed that fundamental rights can be limited 'on condition that the substance of these rights is left untouched'. ${ }^{97}$ Furthermore, in Hauer, the European Court of Justice responded to the parties' vigorous debate on the substance of fundamental rights ${ }^{98}$ by equally including the notion of the very substance as one of the criteria to assess the legitimacy of fundamental rights restrictions. ${ }^{99}$ Even though, as argued above, the EU concept of essence is per se

\footnotetext{
${ }^{95}$ In the seminal case, ECJ 4/73, Nold $v$ Commission, ECLI:EU:C:1974:51, para. 14, the ECJ pointed out that restrictions of fundamental rights are legitimate if they are 'justified by the overall objectives pursued by the Community, on condition that the substance of these rights' is not affected. Emphasis added. In the following case law, this formulation slightly changed, requiring that the interference should not be disproportionate and should not impinge upon the 'very substance' of the rights guaranteed. Cf for example ECJ Case C-44/79, Hauer v Land Rheinland-Pfalz, ECLI:EU: C:1979:290, para. 23, 30; ECJ Case 265/87, Schräder v Hauptzollamt Gronau, ECLI:EU: C:1989:303, para. 15; ECJ Case C-274/99 P, Connolly v Commission, ECLI:EU:C:2001:127, para. 111.

${ }^{96}$ ECJ Case 4/73, Nold v Commission, ECLI:EU:C:1974:51, para. 12.

${ }^{97}$ Ibid., para. 14. Emphasis added.

${ }^{98}$ ECJ C-44/79, Hauer v Land Rheinland-Pfalz, ECLI:EU:C:1979:290. For example, the German government specifically argued that the disputed German measure did 'not adversely affect the 'substance' of the right to property' (p. 3733) and the Council relied directly on the case law of the German Constitutional Court to argue the necessity of the protection of the substance of fundamental rights in the Community legal order and to conclude that the present case did not entail an interference with the substance of the right to property (p. 3736-3737).

${ }^{99}$ Hauer, para. 23: 'whether the restrictions introduced by the provisions in dispute in fact correspond to objectives of general interest pursued by the Community or whether, with regard to
} 
an autonomous concept, ${ }^{100}$ the European Court of Justice developed the concept with inspiration from national constitutional traditions. ${ }^{101}$

It is interesting to observe that the very substance reasoning marked not only the early case law; it persevered in the Court's jurisprudence even after the entry into force of the Charter. Indeed, in some of those cases the use of the very substance reasoning, instead of relying directly on Article 52(1) of the Charter, is due to non-applicability of the Charter, either ratione personae ${ }^{102}$ or ratione temporis. ${ }^{103}$ For example, in Polkomtel, ${ }^{104}$ the European Court of Justice relied on the reasoning establishing fundamental rights as general principles, including the prohibition against violation of the 'very substance' of those rights, because the facts occurred prior to the entry into force of the Charter. ${ }^{105}$ In other cases, the Court used this notion also in post-Charter jurisprudence. For example, in $G$ and $R,{ }^{106}$ Texdata Software ${ }^{107}$ and Križan, ${ }^{108}$ the Court expressly established that the Charter was applicable, but used the very substance formulation instead of Article 52(1) when assessing the restriction of fundamental rights. Another example is UPC Telekabel Wien, where the Court invoked the fundamental rights from the Charter but, without relying on either Article 52(1) or the formula on restrictions, jumped to the conclusion that the very substance of the fundamental right was not affected. ${ }^{109}$ In Councilv Manufacturing Support \& Procurement Kala

the aim pursued, they constitute a disproportionate and intolerable interference with the rights of the owner, impinging upon the very substance of the right to property'.

${ }^{100}$ For convincing reasoning that 'the EU legal order is de facto and de jure far less autonomous than the European Court of Justice pretends it to be', see J.H. Reestman and L. Besselink, 'Sandwiched between Strasbourg and Karlsruhe: EU Fundamental Rights Protection', 12(2) EuConst (2016) p. 213.

${ }^{101}$ It is interesting to observe that the ECJ, in that early period, developed the protection of very substance in German cases, either through preliminary references made by German courts or in cases where German applicants challenged the validity of Community measures.

${ }^{102}$ In ECJ Case C-249/13, Boudjlida, ECLI:EU:C:2014:2431, para. 32, 33; and ECJ Case C-166/13, Mukarubega, ECLI:EU:C:2014:2336, para. 44, the Charter did not apply because it is not addressed to the Member States. Instead, the fundamental rights as general principles were applicable which leads to an interesting conclusion: general principles enjoy a broader scope of application than the Charter.

${ }^{103}$ ECJ Case C-397/14, Polkomtel, ECLI:EU:C:2016:256, para. 60.

${ }^{104}$ See Polkomtel, supra n. 103, para. 60; ECJ Case C-129/13, Kamino International Logistics, ECLI:EU:C:2014:2041, para. 29. See also ECJ Case C-539/10 P, Al-Aqsa v Council, ECLI:EU: C:2012:711, para. 121; ECJ Case C-548/09 P, Bank Melli Iran v Council, ECLI:EU:C:2011:735, para. 114, where the ECJ did not specifically raise the issue of non-applicability of the Charter, but this can be implicitly concluded from the occurrence of facts of the case.

${ }^{105}$ Polkomtel, supra n. 103, para. 60.

${ }^{106}$ ECJ Case C-383/13 PPU, G. and R., ECLI:EU:C:2013:533, para. 32-33.

${ }^{107}$ ECJ Case C-418/11, Texdata Software, ECLI:EU:C:2013:588, para. 71-77 and 84.

${ }^{108}$ ECJ Case C-416/10, Križan, ECLI:EU:C:2013:8, para. 111-116.

${ }^{109}$ ECJ Case C-314/12, UPC Telekabel Wien, ECLI:EU:C:2014:192, para. 47, 51. 
Naft, the Court, deciding in an appeal procedure, initially referred to Article 52(1), and then, when deciding on the merits of the case, made use of the old formula without mentioning Article 52(1). ${ }^{110}$ Admittedly, reliance on either 'very substance' or 'essence' reasoning does not affect the outcome of the inquiry into whether there had been an interference with the core of a particular fundamental right. In both cases, the European Court of Justice seemed to ascribe to the two concepts an equivalent meaning as well as a value independent from the principle of proportionality and thus confirmed the applicability of the absolute theory in the EU legal order.

\section{Essence in the jurisprudence of the ECHR and the European Court of Human Rights}

In the multi-level fundamental rights structure, both the Charter and the ECHR aim to protect the essence of fundamental rights. Adding this additional layer to the protection of the 'essence' of fundamental rights does not create any tension between the two European levels of fundamental rights protection. On the contrary, from the perspective of constitutional pluralism such an additional level of protection, characterised by heterarchy rather than hierarchy, in principle leads to the convergence of legal orders. ${ }^{111}$

Contrary to the Charter, the ECHR does not contain a specific requirement to protect the 'essence' or the 'core' of fundamental rights. ${ }^{112}$ However, what seems to be absolute silence on this issue could be broken by the voice of other provisions of the ECHR. It has been claimed that Article 17 ECHR, which prohibits the abuse of rights, could be seen as protecting the core of such rights. ${ }^{113}$ According to this provision, the ECHR may not 'be interpreted as implying for any State, group or person any right to engage in any activity or perform any act aimed at the destruction of any of the rights and freedoms set forth herein. ${ }^{114}$ It is possible to argue that, through a purposive interpretation of this provision, it can be understood as aiming to protect the essence of the fundamental rights enshrined in the ECHR. The prohibition against the destruction of any of the rights and freedoms contains a hypothesis of the total abolition of rights. This understanding of essence is somewhat narrower than the one in the constitutional orders of the EU and the Member States in that it limits the concept of essence to the prohibition against the abolition of rights. While such an abolition indeed leads to interference with the rights' essence, this interpretation does not include other interferences with the essence with regard

${ }^{110}$ ECJ Case C-348/12 P, Council v Manufacturing Support \& Procurement Kala Naft, ECLI:EU: C:2013:776, para. 122, 123.

${ }^{111}$ Fabbrini, supra n. 41, p. 20-21.

${ }^{112}$ Grote and Marauhn, supra n. 15, p. 369.

${ }^{113}$ Von Bernstorff, supra n. 12, p. 170.

${ }^{114}$ Emphasis added. 
to right holders. Further guidance on the concept of essence is provided by the European Court of Human Rights. Several of its cases relate to interference with the essence of a fundamental right, albeit in rather different contexts, for example on the right of access to the courts (Article 6(1) ECHR), ${ }^{115}$ the privilege against self-incrimination and the right to remain silent, ${ }^{116}$ the right to marry ${ }^{117}$ or the right to vote. ${ }^{118}$ As we will see in the further analysis, this case law partially adheres to the relative and partially to the absolute theory, without a coherent approach to the conceptualisation of the notion of essence. The European Court of Human Rights case law is therefore only a limited source for what we consider a correct normative conceptualisation of the notion of essence in the EU legal order. Moreover, it is difficult to see strong causality or a direct impact of the European Court of Human Rights case law on the concept of essence in the EU legal order. Nevertheless, while there is no explicit evidence for such an impact either in the Explanations to the Charter or in the European Court of Justice case law, there is evidently room for such influence through Article 52(3) of the Charter which requires that the meaning and scope of Charter rights is the same as those from the European Convention of Human Rights, all while allowing the EU legal order to offer more extensive protection when it comes to the essence of a fundamental right. The future case law of the European Court of Justice will hopefully demonstrate the exact scope of the impact of European Court of Human Rights jurisprudence in this regard.

\section{CONCEPTUALISING THE NOTION OF 'ESSENCE' OF FUNDAMENTAL RIGHTS}

How should the notion of 'essence' be conceptualised and its content determined? Just as Raz, when asking himself what 'counts as an explanation of concept', came to the conclusion that 'it consists of setting out some of its necessary features', ${ }^{119}$ it needs to be elaborated what the defining features of the concept of essence should be. A normative conceptualisation of a right's essence is not an easy task, in particular due to an outward absence of a coherent methodological tool that helps to define such a concept or outline its application in practice. ${ }^{120}$ Nevertheless, it is submitted that certain defining elements can be put forward with regard to the concept of essence.

${ }^{115}$ Philis v Greece, supra n. 11, paras 59, 65. Compare later cases ECtHR Baka v Hungary, supra n. 11, para. 121; Al-Dulimi and Montana Management Inc. v Switzerland, supra n. 11, para. 151.

${ }^{116}$ Heaney and McGuinness v Ireland, supra n. 11, para. 55, 58.

${ }^{117}$ Christine Goodwin v United Kingdom, supra n. 11, paras 99-101.

${ }^{118}$ ECtHR, 18 February 1999, Case No. 24833/94, Matthews v United Kingdom, para. 65.

${ }^{119}$ J. Raz, 'Two Views of the Nature of the Theory of Law. A Partial Comparison', in J.L. Coleman (ed.), Hart's Postscript. Essays on the Postscript to The Concept of Law (Oxford University Press 2001) p. 8.

${ }^{120}$ Dawson points out that the ECJ's case law does not clearly draw the boundaries between the 'core' and 'periphery' of fundamental rights; see M. Dawson, The Governance of EU Fundamental Rights (Cambridge University Press 2017) p. 64. 
Following the national constitutional traditions as well as the case law of the European Court of Justice and the European Court of Human Rights, it is submitted that each ${ }^{121}$ fundamental right has an inalienable core which cannot be impinged upon. In abstracto, it is possible to have a theoretical idea of what the essence should be; however, the actual essence of each fundamental right can be determined only in its application. When an essence is interfered with, it can be clearly seen what constitutes the essence of a particular fundamental right. This is important to keep in mind as the essence of a fundamental right can be interfered with in many different circumstances. ${ }^{122}$ For example, if a person receiving a decision from an authority affecting her legal status by law has no means of challenging that decision, this would most likely amount to an interference with the essence of her fundamental right to effective judicial protection. In this case, the interference with essence occurs because she was denied her right to a legal remedy. Another example of interference with the essence of a fundamental right occurs in cases where the right holder has a remedy for challenging the decision issued by a public authority, but the deadline to challenge the decision is so short that no reasonable claimant could ever be able to meet the deadline. In both cases (no remedy or too short a deadline), the essence of the fundamental right to effective judicial protection would be interfered with, despite the differing circumstances.

Below, we seek to conceptualise interferences with the essence by classifying them into different categories. This aims to provide an improved account compared to national or European Court of Human Rights approaches as to how the essence should be understood. Through classification, we seek to get a better overview as to who the addressees of the essence are and in what circumstances the essence of their rights can be interfered with. This theoretical account is thus aimed at facilitating the correct identification of the interference with essence in practice. Below, the categorisations into objective and subjective interferences with the essence are explained, together with the interference with an absolute right.

\section{Objective interference with the essence}

An objective interference with essence implies the illegitimate restriction of a fundamental right in a way that the right's existence is impaired. Such interference would lead to non-existence of the right for all right holders. ${ }^{123}$ The notion of

\footnotetext{
${ }^{121}$ We admit that this claim has not been empirically proven, but it is rather a result of argumentative logic.

${ }^{122}$ Compare T. Ojanen, 'Making the Essence of Fundamental Rights Real: The Court of Justice of the European Union Clarifies the Structure of Fundamental Rights under the Charter: ECJ 6 October 2015, Case C-362/14, Maximillian Schrems v Data Protection Commissioner', 12(2) EuConst (2016) p. 326.

${ }^{123}$ Cf Barak, supra n. 25, p. 497.
} 
essence or core of rights seeks to prevent a 'constitutional rights provision from being so reduced that it becomes meaningless for all individuals, or for a large part of them, or for life in society generally. ${ }^{124}$ According to the German doctrine, the addressee of the prohibition on interference with the essence is primarily the legislature ${ }^{125}$ which is competent to decide on the possibility of a restriction of rights. This was also a historical goal of the German Wesensgehaltgarantie, ${ }^{126}$ which aimed to prevent, after the Second World War, the Nazi-like restrictions of fundamental rights during wartime. ${ }^{127}$ In the constitutions or judicial practices of certain other Member States, the legislature is equally bound to respect the essence of fundamental rights: for example in the Austrian legal system where this notion does not appear in the Constitution, but was developed by the judiciary; ${ }^{128}$ this tendency can be observed also in the Spanish ${ }^{129}$ legal order. The Spanish constitutional court thus rightly considered that 'the essential content is destroyed if the interests that the right protects can no longer be served, as a result of unreasonable restrictions'. ${ }^{130}$ For reasons explained earlier in this article, this reasoning, stemming from the constitutions of different Member States, should also be valid for the interpretation of the notion of 'essence' contained in Article 52(1) of the Charter.

If a particular fundamental right is restricted by the legislature, it is possible that such a restriction interferes with the essence of this fundamental right. ${ }^{131}$ For example, if the constitutional legislature restricts the right to marry or if the ordinary legislature lays down conditions for the exercise of this right stipulating that only people under the age of 25 have the right to marry, such a limitation would naturally interfere with the essence of the right to marry. The essence of fundamental rights can also be impinged upon by other public authorities, for example national administrative authorities. This would be particularly relevant if the national administrative authorities acted within the scope of application of the Charter whenever they were 'implementing Union law' within the meaning of Article 51(1) of the Charter and the Fransson judgment. ${ }^{132}$

${ }^{124}$ Alexy, supra n. 22, p. 193.

${ }^{125}$ Enders, supra n. 47, p. 733, 741-742.

${ }^{126}$ Kokott, supra n. 32, p. 886.

${ }^{127} \mathrm{~L}$. Wildhaber, 'Limitations on Human Rights in Times of Peace, War and Emergency: A Report on Swiss Law', in A. de Mestral (ed.), The Limitation of Human Rights in Comparative Constitutional Law (Yvon Blais 1968) p. 55, who gives as an example Nazi anti-Jewish legislation impairing the essence of personal liberty. Cf also Van der Schyff, supra n. 26, p. 132.

${ }^{128}$ Kokott, supra n. 32, p. 889.

${ }^{129}$ Casas Baamonde and Rodríguez-Piñero y Bravo-Ferrer, supra n. 31, p. 1168; V. Ferreres Comella, The Constitution of Spain: A Contextual Analysis (Hart 2013) p. 237.

${ }^{130}$ Ferreres Comella, supra n. 129, p. 248.

${ }^{131}$ Cf Kokott, supra n. 32, p. 889.

${ }^{132}$ ECJ Case C-617/10, Aklagaren v Åkerberg Fransson, ECLI:EU:C:2013:105, para. 21 where the ECJ points out that 'the fundamental rights guaranteed by the Charter must ... be complied with 
In the context of objective interference with fundamental rights, it is necessary to analyse the most important case ${ }^{133}$ in which the European Court of Justice established an interference with the essence of fundamental rights: Schrems. ${ }^{134}$ In Schrems, the Court annulled the Commission Decision on the adequacy of Safe Harbour ${ }^{135}$ by which the Commission found that the US Safe Harbour Privacy Principles guaranteed an adequate level of protection when data is transferred from the EU to the US. ${ }^{136}$ The Schrems case has to be understood in the broader context of Snowden's revelations disclosing that even those US companies certified in Privacy Principles fed the US authorities, notably the US National Security Agency, with data on European data subjects for the purpose of surveillance. In this case, the European Court of Justice delved into the question of whether the Safe Harbour offered effective remedies for European data subjects and whether the right to privacy of those data subjects had been infringed upon. In its analysis, the Court found interference with the essence of two fundamental rights - the right to privacy and the right to effective judicial protection. ${ }^{137}$

First, regarding the European Court of Justice's finding of interference with the essence of the right to effective judicial protection, it can be noted that the Court proceeded from the premise that the right holder seems to have been deprived of the entirety of protection offered by this fundamental right. In the case at hand, the data subject did not have any possibility at all 'to pursue legal remedies in order to have access to personal data relating to him, or to obtain the rectification or erasure of such data. ${ }^{138}$ It can be claimed that the Court's finding was not only reasonable and followed a clear perception of the deficiency leading to the fundamental right infringement, but also the only possible solution given the factual background in Schrems. Even though the Court did not give any further explanation as to the content and meaning of 'essence', it can be understood from its approach that depriving the right holder of the protection given by this

where national legislation falls within the scope of European Union law' and that the 'applicability of European Union law entails applicability of the fundamental rights guaranteed by the Charter'.

${ }^{133}$ In Alemo-Herron and Others, supra n. 37, paras 35-36, the ECJ, in the context of an interpretation of a directive, pointed out that a national regime concerning collective bargaining is liable to adversely affect the very essence of its freedom to conduct a business' and that secondary legislation cannot be interpreted in a way so as to affect this essence.

${ }^{134}$ Schrems, supra n. 4.

${ }^{135}$ Commission Decision 2000/520/EC of 26 July 2000 pursuant to Directive 95/46/EC of the European Parliament and of the Council on the adequacy of the protection provided by the safe harbour privacy principles and related frequently asked questions issued by the US Department of Commerce (notified under document number C(2000) 2441), [2000] OJ L 215/7.

${ }^{136}$ Schrems, supra n. 4, para. 107.

${ }^{137}$ It is interesting to note that AG Bot only found a breach of essence of the fundamental rights to privacy and data protection. See Opinion of AG Bot in Schrems, supra n. 4, para. 177.

${ }^{138}$ Schrems, supra n. 4, para. 95. 
fundamental right amounts to an interference with the essence of this right. The right holder is offered no protection, since she does not have at her disposal any remedies whatsoever to protect her rights. The Court further links this impairment of essence with the rule of law, pointing out that the 'existence of effective judicial review...is inherent in the existence of the rule of law'. ${ }^{139}$ In a democratic society based on rule of law, members of society should not be left entirely without remedies against acts which have a legal effect on them.

Secondly, the European Court of Justice in Schrems also established an interference with the essence of the fundamental right to privacy since, under the auspices of Safe Harbour, the public authorities could 'have access on a generalised basis to the content of electronic communications' of data subjects. ${ }^{100}$ It seems that the interference with the essence of this fundamental right was found because data subjects are completely stripped of their privacy since any of their electronic communications could be read by public officials, leaving them no space to keep even the most private of information. Situated in the context of broader case law, Schrems is a rather unsurprising ruling, given the fact that the ground for such a path was paved already in Digital Rights Ireland, ${ }^{141}$ where an interference with the essence of the fundamental right to privacy was not found because the Data Retention Directive ${ }^{142}$ at stake in this case did not allow any person to acquire knowledge of the content of electronic communication. ${ }^{143}$ Something that may seem like simple a contrario reasoning from previous precedent raises both practical and doctrinal uncertainties.

From a practical perspective, it is questionable whether the distinction between having access to the content of electronic communications and acquiring knowledge about the metadata of electronic communications should really be differentiated to the extent that it leads to different types of fundamental rights violations. One can very well imagine situations where acquiring knowledge about metadata reveals sensitive information about relationships between different data subjects and even the identity of those subjects, as confirmed by the European Court of Justice in Tele2 Sverige. ${ }^{144}$ In this judgment, national courts from the UK and Sweden asked the European Court for clarification as to the possibility of continuing to apply national legislation on data retention after the annulment of

${ }^{139}$ Schrems, supra n. 4, para. 95.

${ }^{140}$ Schrems, supra n. 4, para. 94.

${ }^{141}$ Digital Rights Ireland, supra n. 3.

${ }^{142}$ Directive 2006/24/EC of the European Parliament and of the Council of 15 March 2006 on the retention of data generated or processed in connection with the provision of publicly available electronic communications services or of public communications networks and amending Directive 2002/58/EC, OJ 2006 L 105, p. 54.

${ }^{143}$ Digital Rights Ireland, supra n. 3, para. 39.

${ }^{144}$ See Tele2 Sverige, supra n. 38. 
the Data Retention Directive. The national legislation provided for the possibility of access to electronic communications metadata, but not to its content. As Advocate General Saugmandsgaard Øe correctly pointed out, the risks related to access to metadata could be just as serious or even more serious than those brought about by access to content data. ${ }^{145}$ The European Court of Justice followed this approach and rightly specified that metadata 'taken as a whole, is liable to allow very precise conclusions to be drawn concerning the private lives of the persons whose data has been retained, such as everyday habits, permanent or temporary places of residence, daily or other movements, the activities carried out, the social relationships of those persons and the social environments frequented by them'. ${ }^{146}$ Moreover, sometimes information about metadata and content data can be mixed, for example access to frequency of electronic exchange and (even randomly selected) keywords from such a communication. Finally, it is also not clear into which category encrypted data would be classified, insofar as it does not immediately give direct, but rather potential, information about the content that can be revealed upon the decryption of such data.

From the doctrinal perspective of objective interference with essence, the Court's conclusion on the interference with the right to privacy in Schrems seems an unfortunate mixture of application of the part of proportionality requiring an interference to be 'strictly necessary' and a conclusion on interference with the essence of the fundamental right to privacy through a contrario reasoning from Digital Rights Ireland. With the application of this incomplete proportionality test, the Court seems to have deliberately avoided the prong of proportionality requiring an interference to be appropriate for attaining legitimate objectives, and this is because it failed to identify such legitimate objectives. It is submitted that the cause for following such an approach in Schrems does not necessarily need to be explained by a noble constitutional rationale, but alternatively by practical reasons connected to difficulties in the application of the proportionality test in circumstances where an interference with privacy takes place in a third country. ${ }^{147}$

Following this line of reasoning, establishing an interference with essence could be seen as an elegant way for the Court to avoid the above-mentioned part of the proportionality test in the factual circumstances by which US authorities had access to the data of European data subjects. A hurdle that the Court would need to overcome is the determination whose 'national security' could be qualified as an

\footnotetext{
${ }^{145}$ Opinion of AG Saugmandsgaard Øe in ECJ Case C-203/15, Tele2 Sverige, ECLI:EU: C:2016:572, para. 259.

${ }^{146}$ See Tele2 Sverige, supra n. 38, para. 99.

${ }^{147}$ See also L. Azoulai and M. van der Sluis, 'Institutionalizing personal data protection in times of global institutional distrust: Schrems Case C-362/14, Maximillian Schrems v Data Protection Commissioner, joined by Digital Rights Ireland, judgment of the Court of Justice (Grand Chamber) of 6 October 2015, EU:C:2015:650', 53 Common Market Law Review (2016) p. 1365-1366.
} 
overriding reason in the public interest that needs to be balanced against data protection. ${ }^{148}$ Of course, it was EU legislation (Decision 2000/520 ${ }^{149}$ ) which, by declaring that the Safe Harbour guarantees adequate protection and by authorising the transfer of data through this agreement to the US, allowed for such an interference with the fundamental right to privacy. Indeed, this is the reasoning that led the European Court of Justice to the annulment of Decision 2000/520. ${ }^{150}$ According to this Decision, '[US] national security, public interest, or law enforcement requirements ${ }^{151}$ prevail over principles from Safe Harbour: this would lead to the conclusion that US companies should not respect those principles if US national security or other overriding interests were at stake. Thus, if the Court decided to follow the full proportionality path, it would have needed to balance the objectives of domestic (EU) legislation with the foreign overriding requirement of (US) national security. Finding an interference with the essence of a fundamental right to privacy could therefore have been just pretence for avoiding the hurdle of having to perform such a balancing exercise. Because the European Court of Justice seems to allow privacy restrictions to be justified by such reasons, a more appropriate answer would be for the Court to find the existence of a (particularly serious) interference instead of finding the interference with the essence of privacy.

If we apply the theoretical framework on objective interference with the essence to European Court of Human Rights case law, cases can be identified that fit the scheme. It can be discerned from this case law that the Convention rights cannot be interpreted in a way so as to diminish a particular fundamental right for all its addressees in particular circumstances. ${ }^{152}$ Those are cases where the right holder is put in a position where she cannot, by any means, exercise her fundamental right, as the right is completely denied to her. For example, in Baka v Hungary, ${ }_{153}$ the President of the Hungarian Supreme Court whose mandate had been terminated

\footnotetext{
${ }^{148}$ The use of the term 'national security' rather than 'public security' follows the Schrems judgment and does not refer to 'national security' as understood in Art. 4(2) TEU, according to which national security 'remains the sole responsibility of each Member State'. The use of this term shows all the more that the 'security' in question in this case is US national security. For a discussion on this issue, see A. Dimitrova and M. Brkan, 'Balancing National Security and Data Protection: The Role of EU and US Policy-Makers and Courts before and after the NSA Affair', Journal of Common Market Studies (2017) p. 10.

${ }^{149}$ Commission Decision 2000/520/EC of 26 July 2000 pursuant to Directive 95/46 on the adequacy of the protection provided by the safe harbour privacy principles and related frequently asked questions issued by the US Department of Commerce, OJ 2000 L 215, p. 7.

${ }^{150}$ Schrems, supra n. 4, para. 98.

${ }^{151}$ Schrems, supra n. 4, para. 86.

${ }^{152}$ As argued above, for an abstract (and narrower conception of) interference with the essence of ECHR fundamental rights, see Art. 17 ECHR.

${ }^{153}$ Baka v Hungary, supra n. 11, paras 120-122.
} 
as a consequence of controversial constitutional changes had no legal means whatsoever to challenge this termination. Accordingly, the European Court of Human Rights found an interference with the essence of his right to access to a court (Article 6(1) ECHR). Comparably, in Matthews v United Kingdom, ${ }^{154}$ Ms Matthews, residing in Gibraltar, was denied the right to vote in the European Parliament elections which led to an interference with the essence of her right to vote. ${ }^{155}$ The non-availability and denial of the exercise of a certain fundamental right can therefore be considered to amount to an interference with the essence. Furthermore, in Goodwin v United Kingdom, ${ }^{156}$ the essence of the right to marry ${ }^{157}$ of Ms Goodwin, born as a man and having had an operatively re-assigned gender as a woman, was impaired because she had, as a woman, no possibility to marry a man. ${ }^{158}$ In this rather revolutionary decision, ${ }^{159}$ the European Court of Human Rights clearly recognised that a denial of a right leads to interference with the essence of that right.

\section{Subjective interference with the essence}

Contrary to objective interference, subjective interference with the essence does not result in the right being excessively restricted for all right holders, but rather that such a right does not exist or ceases to exist for a particular right holder or group of right holders. The essence of rights thus relates to the individual position of the right holder. ${ }^{160}$ This category comes relatively close to the objective category discussed above, with the difference that the latter works at an abstract level and hence leads to the non-existence of a particular fundamental right in general, whereas, in the subjective category, there is 'nothing left' of a fundamental right for a particular addressee, that is the person invoking the fundamental right. Let us take the right to life as an example: the killing of a person by a policeman without a justification for the killing amounts to an interference with the essence of that person's right to life. ${ }^{161}$

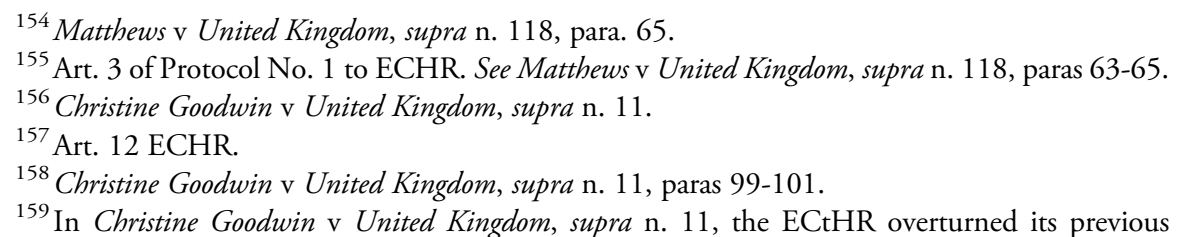
jurisprudence on the right to marry for transsexuals: ECtHR 17 October 1986, Case No. 9532/81, Rees v United Kingdom; ECtHR 27 September 1990, Case No. 10843/84, Cossey v United Kingdom; ECtHR 30 July 1998, Case Nos. 31-32/1997/815-816/1018-1019, Sheffield and Horsham v United Kingdom.

${ }^{160}$ Cf Alexy, supra n. 22, p. 192-193.

${ }^{161}$ Cf Barak, supra n. 25, p. 497. That person is also deprived of (the essence of) all other fundamental rights since without life, no other fundamental right has a meaning; see J. Schwarze (ed.), EU Kommentar, $3^{\text {rd }}$ edn. (Nomos 2012) p. 2618. 
Looking into the case law of the European Court of Justice, an example of a subjective interference is the Zambrano case and the subsequent case law on infringement of the violation of the 'substance' (l'essentiel, Kernbestand ${ }^{162}$ ) of EU citizenship rights. ${ }^{163}$ Even though the case law on citizens' rights does not make an explicit link to the fundamental rights aspects of citizenship, such a connection between the two sets of rules can be presupposed from the inclusion of citizen's rights into the Charter. ${ }^{164}$ While the Court makes a clear distinction between Articles 20 and 21 TFEU and links the infringement of substance to the former provision (qua content its paragraph 1), it is however not entirely clear which article of the Charter would overtake the function of this Treaty paragraph.

Yet, this seeming lacuna could be overcome if the reasoning on citizenship being the 'fundamental status of nationals of the Member States ${ }^{165}$ were to be read into the interpretation of the Charter's articles on citizenship. In any event, the essence of a citizen's fundamental right (embedding her fundamental status) would be affected if EU citizen(s) - just as in Zambrano ${ }^{166}$ or $N A,{ }^{167}$ - needed to leave the Union's territory altogether. Similarly, the automatic deportation of a national of a Member State who does not have the capacity to produce documents required to obtain a residence permit would amount to an impairment of her (fundamental) right of residence. ${ }^{168}$ Even though the reasons for the infringement of essence and substance might differ, the rationale behind the infringement of the essence of a fundamental right and of the substance of citizens' rights follows the same line of reasoning. In both cases, the right itself ceases to exist for the right holder; we are not facing only an unjustified or disproportionate interference, but an interference where the addressee of the right is not in a position to exercise her rights.

\footnotetext{
${ }^{162}$ Part of the German doctrine argues that the notion of Wesensgehalt - just as the notion depicting 'essence' in the German Constitution - should be used instead of the term Kerngehalt. See A. Wallrabenstein, '21, 18, Zambrano - Zum Wesensgehalt der Unionsbürgerreche', in C. Franzius et al., Grenzen der europäischen Integration (Nomos 2014) p. 320.

${ }^{163}$ ECJ Case C-34/09, Ruiz Zambrano, ECLI:EU:C:2011:124, para. 42; ECJ Case C-202/13, McCarthy and Others, ECLI:EU:C:2014:2450, para. 57; ECJ Case C-256/11, Dereci and Others, EU:C:2011:734, paras 66 and 67; ECJ Case C-40/11, Iida, EU:C:2012:691, para. 71; ECJ Case C-87/12, Ymeraga and Others, EU:C:2013:291, para. 36; ECJ Case C-86/12, Alokpa and Moudoulou, EU:C:2013:645, para. 32; ECJ Case C-115/15, NA, ECLI:EU:C:2016:487, para. 72. Compare also the analysis of case law in the Opinion of AG Szpunar in ECJ Cases C-165/14 and C-304/14, Rendón Marin and CS, EU:C:2016:75.

${ }^{164}$ Von Bogdandy et al., supra n. 21, p. 506.

${ }^{165}$ ECJ Case C-184/99, Grzelczyk, EU:C:2001:458, para. 31; Ruiz Zambrano, supra n. 163, para. 41; ECJ Case C-115/15, NA, ECLI:EU:C:2016:487, para. 70.

${ }^{166}$ Ruiz Zambrano, supra n. 163, para. 42.

${ }^{167}$ ECJ Case C-115/15, NA, ECLI:EU:C:2016:487, para. 72.

${ }^{168}$ ECJ Case C-408/03, Commission v Belgium, ECLI:EU:C:2006:192, para. 68.
} 


\section{Absolute (interference with) essence}

As mentioned above, a special category of interference with essence are interferences with absolute rights, that is, rights which are inviolable and which can under no circumstances be restricted. They represent the foundation of democratic human society and embed the core values of this society. Typical examples of absolute rights are the prohibition against slavery or forced labour ${ }^{169}$ and the prohibition on torture and inhuman or degrading treatment. ${ }^{170}$ For example, the ECHR, apart from the prohibition on torture and slavery, also contains the right not to be convicted if certain conduct was not an offence at the time the conduct occurred ${ }^{171}$ and the prevention of having a heavier penalty imposed than the one existing at the time of the offence. ${ }^{172}$ Absolute rights form a limited yet separate category of rights, the restriction of which would lead to an abrogation of the foundations of a valuebased society that respects human dignity. Rights such as the prohibition of torture or the prohibition of child labour do not themselves have a separate core because they are the core themselves; it is thus meaningless to search for additional essence in those absolute rights because they are, as a whole, inviolable. In principle, even the smallest restriction of such rights leads to their impairment as an embodiment of essence. In practice, the assessment of the interference with an absolute right therefore shifts to the question of whether certain behaviour falls within the scope of this right. For example, the legal battlefield shifts to the question of whether torture had indeed taken place which brings the focus of the discussion to a detailed analysis of whether the threshold to qualify behaviour as torture was met. In the case law of the European Court of Human Rights, for example, there is a threshold of severity to be met in order to determine whether someone has been subjected to torture or inhuman or degrading treatment. The Court developed criteria for a three-tier hierarchy as to when a behaviour constitutes torture, inhuman treatment or degrading treatment. ${ }^{173}$ If a behaviour does not reach this threshold, the absolute fundamental right is not interfered with.

The importance of absolute rights in the EU legal order and their close link to human dignity was pointed out in the joint cases Aranyosi and Căldăraru ${ }^{174}$

${ }^{169}$ Art. 4 of the Charter.

${ }^{170}$ Art. 5 of the Charter.

${ }^{171} \mathrm{~A}$ discussion on the exceptions to this right, such as for war crimes committed during the Second World War, goes beyond the scope of this article.

${ }^{172}$ See in more detail S. Greer, The Margin of Appreciation: Interpretation and Discretion under the European Convention on Human Rights (Council of Europe Publishing 2000) p. 27.

${ }^{173}$ For a detailed analysis see Y. Arai, 'Grading Scale of Degradation: Identifying the Threshold of Degrading Treatment or Punishment under Article 3', 21(3) Netherlands Quarterly of Human Rights (2004) p. 385-421.

${ }^{174}$ ECJ Joined Cases C-404/15 and C-659/15 PPU, Aranyosi and Căldăraru, ECLI:EU: C:2016:198. 
regarding Hungarian and Romanian nationals respectively who, after their arrest in Germany, were supposed to be returned to their countries of origin where the conditions of retention reportedly violated the prohibition against inhuman and degrading treatment. It is important to point out that the European Court of Justice recognised that 'the prohibition of inhuman or degrading treatment ... is absolute in that it is closely linked to respect for human dignity'. ${ }^{175}$ From this narrative - both from the absolute nature of this particular fundamental right as well as the link to human dignity - a close connection to the concept of essence can be established. The essence as the absolute core of rights protects the entire scope of application of absolute rights. Aranyosi thus offers a good example of the circumstance that even a minor infringement of absolute fundamental rights would pierce the penumbra of essence. ${ }^{176}$ In consequence, when determining whether there was an interference with any of the absolute rights, the principle of proportionality never applies and, hence, renders irrelevant the discussion on relative or absolute theory regarding this type of right.

\section{DETERMINING INTERFERENCE WITH ESSENCE IN THE EUROPEAN}

\section{LEGAL ORDER}

In this part of the article, we seek to determine a methodology for systematically establishing whether there has been an interference with the essence of a fundamental right.

\section{Endorsement of the exclusionary approach}

Elaborating on the findings relating to the absolute and relative theories, it is proposed that the European legal order should endorse the absolute approach (which can also be termed an 'exclusionary' approach because it sees the essence and proportionality as two mutually exclusive concepts) rather than the relative approach (which can alternatively be named the 'integrative' approach as it seeks to integrate the concepts of essence and proportionality). This author prefers to use the terms 'exclusionary' and 'integrative' rather than 'absolute' and 'relative' as she considers them to describe the relationship between essence and proportionality in a more precise manner, clearly depicting whether the two tests appear as stand-alone or interconnected tests.

\footnotetext{
${ }^{175}$ Aranyosi and Căldăraru, supra n. 174, para. 85.

${ }^{176}$ Terminologically and content-wise, it is important to distinguish between the core (essence) of a human right and core human rights. The latter are rights that are necessary for a dignified human existence and partially overlap with absolute rights: H. Victor Condé, $A$ Handbook of International Human Rights Terminology (University of Nebraska Press 2004) p. 50.
} 
We consider that the interference with the essence of a fundamental right should not be equated with a 'serious ${ }^{\text {'177 }}$ or even a 'particularly serious interference ${ }^{, 178}$ with this right. This is because such an interference could be, methodologically speaking, subject to justification and proportionality balancing. As long as there is a potential justification for an interference with a fundamental right, it is possible to balance the values protected by a fundamental right with other competing values. The outcome of such balancing can be either a justified or an unjustified interference with a fundamental right, but not an interference with the essence of this right. This is because the essence lies beyond the proportionality exercise and an interference with it does not allow for justification. The essence should thus not be portrayed as equalling an unjustified infringement; in case of an unjustified infringement, a justificatory argument exists but it does not justify because the interference is disproportionate; in case of interference with essence, no justificatory argument exists.

Two arguments support the adoption of this approach in the European legal order. On the one hand, since the essence is to be of an independent value in the EU legal order because the European Court of Justice recognises it as such, it should be possible to define it separately from proportionality, allowing it to play a distinct role in preventing certain limitations. ${ }^{179}$ On the other hand, the exclusionary approach can also be supported by a textual interpretation of Article 52(1) of the Charter which states in its first sentence that any limitations on rights and freedoms must respect their essence, while the principle of proportionality is mentioned only in the second sentence of this provision, elaborating on the conditions under which limitations are allowed.

In the most important case so far in which the European Court of Justice found an interference with essence, Schrems, ${ }^{180}$ the Court did not use proportionality as a tool to determine the interference with the right to effective judicial protection. As argued above, the lack of any remedies for European data subjects to challenge the transfer of data to the US and sharing of this data with US public authorities resulted in a breach of the essence of this fundamental right. When it comes to an interference with the essence of the right

\footnotetext{
${ }^{177}$ See for example ECJ Case C-528/15, Al Chodor and Others, ECLI:EU:C:2017:213, para. 40; ECJ Case C-201/15, AGET Iraklis, ECLI:EU:C:2016:972, para. 99; Order in ECJ Case C-698/15, Watson and Others, ECLI:EU:C:2016:70, para. 10-11; Opinion of AG Saugmandsgaard Øe in ECJ Joined Cases C-203/15 and C-698/15, Tele2 Sverige and Watson, ECLI:EU:C:2016:572, paras 128, 129, 171, 231, 254.

${ }^{178}$ See for example Digital Rights Ireland, supra n. 3, paras 37, 39; ECJ Joined Cases C-203/15 and C-698/15, Tele2 Sverige and Watson, ECLI:EU:C:2016:970, para. 100; Opinion of AG Bot in ECJ Case C-362/14 Schrems, ECLI:EU:C:2015:627, para. 171, 214.

${ }^{179}$ Rivers, supra n. 6, p. 184.

${ }^{180}$ Schrems, supra n. 4, paras 94-95.
} 
to privacy, it would be more appropriate for the European Court of Justice to conclude that this was an unjustified interference with this fundamental right, as explained above.

Turning to the case law of the European Court of Human Rights, we can establish that the relationship between the notions of essence and proportionality as approached by this Court proves to be both close and complex, with the Court failing to follow a clear doctrinal line of reasoning. An exclusionary approach, although perhaps not deliberately chosen, can be noticed in certain cases where an impairment of essence leads to non-application of the proportionality test. The European Court of Human Rights sometimes expressly points out the exclusionary nature of essence and proportionality in its reasoning ${ }^{181}$ or implicitly by simply omitting the proportionality test. ${ }^{182} \mathrm{~A}$ closer look at these cases reveals that they relate to a situation where the right was, from the outset, entirely nonexistent for the applicant. In Al-Dulimi, for example, the applicants had no legal means for challenging the confiscation of their assets as ordered by the United Nations Security Council resolution ${ }^{183}$ and in Baka, the former president of the Hungarian Supreme Court had no legal remedy whatsoever for challenging the decision that prematurely terminated his mandate. ${ }^{184} \mathrm{Ms}$ Matthews, a resident of Gibraltar, did not have the right to vote in the European parliamentary elections. ${ }^{185}$ In these cases the issue was not the degree of limitation of a right, but rather a denial of the right; hence, it was impossible to proceed to the proportionality balancing.

However, the case law of the European Court of Human Rights is not consistent when it comes to the choice of either the exclusionary or the integrative approach. The integrative approach can regularly be found in the case law of the Court and is signalled by an often-used phrase, according to which limitations, to be lawful, should not impair the essence of the right and should pursue a legitimate aim, providing for a 'reasonable relationship of proportionality between the means employed and the aim sought to be achieved'. ${ }^{186}$ This reasoning seems to imply that the essence analysis forms part of the proportionality balancing.

\footnotetext{
${ }^{181}$ Al-Dulimi and Montana Management Inc. v Switzerland, supra n. 11, para. 37.

${ }^{182}$ Baka v Hungary, supra n. 11, para. 122; ECtHR 22 June 2004, Case No. 31443/96, Broniowski v Poland, para. 185; Matthews v United Kingdom, supra n. 118, para. 65.

${ }^{183}$ Al-Dulimi, para. 2 juncto 37.

${ }^{184}$ Baka v Hungary, supra n. 11, para. 121.

${ }^{185}$ Matthews v United Kingdom, supra n. 118, para. 7.

${ }^{186}$ ECtHR 18 February 1999, Case No 26083/94, Waite and Kennedy v Germany, para. 59; ECtHR 21 November 2001, Case No. 35763/97, Al-Adsani v United Kingdom, para. 53; ECtHR 21 November 2001, Case No. 31253/96, McElhinney v Ireland, para. 34; ECtHR 23 March 2010, Case No. 15869/02, Cudak v Lithuania, para. 55; Ashingdane v United Kingdom, supra n. 11, para. 57.
} 
In Kart $\mathrm{v}$ Turkey, ${ }^{187}$ for example, where an immediate conclusion on the interference with the essence was not possible, the Court sought to verify this interference with the essence by referring to the principle of proportionality. Further, in Cudak, a case concerning a Lithuanian employee who had been dismissed from a Polish embassy which then invoked immunity against her claim, the Court began its analysis by verifying the legitimacy of the aim, followed by an assessment of proportionality - the interference with which led to an impairment of an essence of the applicant's right of access to a court. ${ }^{188}$ European Court of Human Rights jurisprudence therefore seems to indicate that there is a certain degree of overlap between the notions of essence and proportionality. Even a claim that 'proportionality ... does not overlap entirely with the protection of the minimum core (or the "essence"),189 could point to the fact that such an overlap could exist. In Şahin, the Court confirmed this overlap by ruling there is no such interference with the essence if the restrictions of a right 'are foreseeable for those concerned and pursue a legitimate aim. ${ }^{190}$

Moreover, in certain cases, the European Court of Human Rights seems to look at the notion of interference with the essence as a question of a(n excessive) degree of limitation, reiterating that 'limitations must not restrict the exercise of the right in such a way or to such an extent that the very essence of the right is impaired'. ${ }^{191}$ An illustrative example is the case law relating to the privilege against self-incrimination and the right to remain silent (Article $6 \mathrm{ECHR}$ ) where this fundamental right was interfered with due to coercion on the part of authorities to provide documents or statements that would incriminate them. Measures used in criminal proceedings against the applicant Funke, ${ }^{192}$ who refused to produce documents that could incriminate him, were designated in later case law as having 'destroyed the very essence of the privilege against self-incrimination' due to the 'degree of compulsion' used against the applicant. ${ }^{193}$ Similarly, in Heaney and McGuinness, the Court concluded that the essence had been impaired due to the degree of compulsion against the applicants who were compelled to provide information relating to charges against them. ${ }^{194}$ By following this approach, the

\footnotetext{
${ }^{187}$ ECtHR 3 December 2009, Case No. 8917/05, Kart v Turkey, paras 93-111.

${ }^{188}$ Art. 6(1) ECHR. Cudak v Lithuania, supra n. 186, paras 60-74.

${ }^{189}$ Dissenting opinion of Judge Pinto de Albuquerque in ECtHR 13 July 2012, Case No. 16354/06, Mouvement raëlien suisse $\mathrm{v}$ Switzerland, footnote 32.

${ }^{190}$ ECtHR 10 November 2005, Case No. 44774/98, Leyla Şahin v Turkey, para. 154.

${ }^{191}$ Emphases added. Al-Dulimi and Montana Management Inc. v Switzerland, supra n. 11, para. 35.

${ }^{192}$ ECtHR 25 February 1993, Case No. 10828/84, Funke v France.

${ }^{193}$ ECtHR 8 February 1996, Case No. 18731/91, John Murray v United Kingdom, para. 49. Emphasis added.

${ }^{194}$ Heaney and McGuinness v Ireland, supra n. 11, paras 55, 58.
} 
European Court of Human Rights seems to confound the interference with the essence of a fundamental right with an interference with this right and thus confusing the test of interference with the essence with proportionality balancing.

\section{Proposal: EU methodology for determining the interference with the essence}

Building on the findings above, this article seeks to construct an EU methodology for the determination of interferences with the essence of fundamental rights. In other words, which abstract criteria should be used in order to determine, in practice, whether there has been an interference with the essence of a particular fundamental right? The proposal regarding an interference with the essence for the EU legal order is inspired by the classification of breaches of essence as well as by the exclusionary (absolute) approach. Against this backdrop, the proposed test is the following.

The essence of a fundamental right is interfered with:

- if the interference with the fundamental right calls into question the existence of the fundamental right either for a particular right holder or for all right holders and

- if overriding reasons for such interference do not exist.

The first part of the test is an embodiment of the objective and subjective interference with essence explained above, leading to a denial of a right to all right holders or a particular right holder. Some cases in which the European Court of Justice decided on an interference with the essence of a fundamental right might already show the readiness of the Court to follow this approach. One example is the Spasic ${ }^{195}$ case regarding the prosecution and sentencing of Mr Spasic in both Italy and Germany; the Court was prompted to decide on a question whether the ne bis in idem principle (Article 50 of the Charter) could be subjected to the condition that the penalty had already been enforced or could no longer be enforced in another Member State. Having established that such a limitation was in fact provided by the Explanations to the Charter, the Court continued its reasoning by affirming that this limitation 'does not call into question the ne bis in idem principle as such. ${ }^{196}$ The test of 'calling into question' a fundamental right 'as such' seems to imply that the limitation should undermine the existence of this right in order to establish an interference with the essence of this right. For example, in the recent Grand Chamber judgment Florescu, tackling the question of whether Romanian legislation not allowing retired judges to combine their

${ }_{195}$ Spasic, supra n. 40. 
pension with income derived from teaching at public universities infringes the right to property (Article 17 of the Charter), the Court established that there was no interference with the essence of the right to property as the legislation did not undermine the 'very principle of the right to a pension'. ${ }^{197}$ Another example in which the Court expressed itself on an interference with essence in the context of an interpretation of a piece of secondary legislation in accordance with the fundamental freedom to conduct a business, is Alemo-Herron. ${ }^{198}$ The Court concluded that a national regime which prevented certain undertakings from participating in the collective bargaining body called upon to decide collective agreements was liable to adversely affect the essence of their freedom to conduct a business. ${ }^{199}$ Alemo-Herron can thus be understood as an example of a case in which the existence of a fundamental freedom was called into question for particular right holders. The absence of such an exclusion of particular undertakings consequently led the Court to deny an interference with essence in AGET Iraklis. ${ }^{200}$

The second part of the test seeks to distinguish interferences with the essence of a right from (un)justified interferences with fundamental rights. The definition of essence of a particular right is thus a negative definition whereby proportionality functions as a mirror in which an interference with the essence can be seen more clearly to ensure that only the most blatant violations of fundamental rights lead to an interference with their essence.

To clarify the criteria contained in the second part of the test: the essence of fundamental rights can be interfered with if it is impossible to identify any overriding reasons. ${ }^{201}$ As Alexy correctly states, 'an absolute guarantee of an essential core cannot say that outweighing reasons do no outweigh, but only that there are no outweighing reasons' ${ }^{202}$ The interference with the essence of the right to effective judicial protection as established in Schrems would fall within this category since the right holder did not have any legal means whatsoever to challenge the data interferences in the context of Safe Harbour. ${ }^{203}$ There were no overriding reasons that could justify this absence of legal remedies, leading to an interference with the essence of this fundamental right. This part of the Schrems reasoning also fulfils the first part of the test as the right to a remedy was entirely denied to right holders.

\footnotetext{
${ }^{197}$ Florescu and Others, supra n. 39, para. 55.

${ }^{198}$ Alemo-Herron and Others, supra n. 37.

${ }^{199}$ Ibid., paras 34-35.

${ }^{200}$ Case C-201/15, Anonymi Geniki Etairia Tsimenton Iraklis (AGET Iraklis), ECLI:EU: C:2016:972, paras 84-88.

${ }^{201}$ It is expected that such examples will be rare in practice as the parties usually bring forward justificatory reasons for interferences with fundamental rights.

${ }^{202}$ Alexy, supra n. 22, p. 195.

${ }^{203}$ See Schrems, supra n. 4, para. 95.
} 
If we were to apply this test to the Schrems case with regard to interference with the right to privacy, we would come to a different conclusion than the European Court of Justice. If the Court had indeed balanced the right to privacy against (US) national security, it would have had to conclude either that this security concern outweighed authorities' access to content data or that this overriding reason could not outweigh such access. In any event, the Court would have ruled that we are facing either a justified interference or a (particularly serious) unjustified interference. As long as it is possible to (out)balance a fundamental right with a competing right or interest, the essence of a right does not come into play.

Finally, establishing interference with the essence of fundamental rights on the basis of the proposed test can in principle have as a consequence an impairment of the values of democratic society enshrined in Article 2 TEU to which the notion of essence is closely linked. ${ }^{204}$ While it is submitted that determination of such consequences is not part of the test itself, it substantiates the raison d'etre of essence, grounded in values upon which the Union was founded, such as human dignity, freedom, democracy or the rule of law. ${ }^{205}$ Essence is, notably, closely related to human dignity. ${ }^{206}$ Fundamental rights, such as the freedoms of religion or expression, to property or equality before the law, are - to a greater or lesser degree - rooted in human dignity. ${ }^{207}$ Human dignity could even be seen as one of the grounds for recognising essence as a separate legal concept as a matter of EU law. ${ }^{208}$ This hypothesis, which appears to be confirmed by the Explanations to the Charter, builds upon the premise that the essence of a fundamental right equals its human dignity core and that touching upon this core would amount to an interference with the essence of a fundamental right. According to the Explanations to Article 1 (human dignity), none of the Charter rights 'may be used to harm the dignity of another person', because 'the dignity of the human person is part of the substance' (la substance) of Charter

\footnotetext{
${ }^{204}$ For the link between the essence and Art. 2 TEU, see further Von Bogdandy et al., supra n. 21, p. $489 \mathrm{ff}$.

${ }^{205}$ These values are also expressly recognised in the Preamble to the Charter: 'the Union is founded on the indivisible, universal values of human dignity, freedom, equality and solidarity; it is based on the principles of democracy and the rule of law'.

${ }^{206} \mathrm{McC}$ rudden points out that every human possesses intrinsic worth merely by being a human and this intrinsic worth should be respected by others: C. McCrudden, 'Human Dignity and Judicial Interpretation of Human Rights', 19(4) European Journal of International Law (2008) p. 679.

${ }^{207}$ M. Kumm and A.D. Walen, 'Human Dignity and Proportionality: Deontic Pluralism in Balancing', in G. Huscroft, B.W. Miller, G. Webber (eds.), Proportionality and the Rule of Law. Rights, Justification, Reasoning (Cambridge University Press 2014) p. 68.

${ }^{208}$ For a more philosophical account of dignity, see M. Rosen, Dignity: Its History and Meaning (Harvard University Press 2012) and for a commentary J. Waldron, 'The Paradoxes of Dignity. About Michael Rosen, Dignity: its History and Meaning (Harvard University Press 2012)', 54(3) European Journal of Sociology (2013) p. 554-561.
} 
rights. ${ }^{209}$ The Explanations further point out that this substance has to 'be respected, even where a right is restricted'. ${ }^{210}$ As Barak correctly argues, human dignity 'comprises the foundation for all of the constitutional rights' and is a 'rationale for them all'. ${ }^{211}$

However, this reasoning does not mean that interference with the essence leads to an infringement of Article 1 of the Charter. This paper follows Barak's distinction between dignity as a 'constitutional value' and dignity as a 'constitutional right'. ${ }^{212}$ A breach of essence does not necessarily lead to an interference with human dignity as a constitutional right, expressly recognised in Article 1 of the Charter and in the pre-Charter European Court of Justice Omega ${ }^{213}$ case, but rather as a constitutional value, ${ }^{214}$ building upon a premise that every fundamental right contains an element of human dignity. Along these lines, the European Court of Justice has already emphasised dignity as a constitutional value for example in the $P \vee S$ case regarding discrimination on grounds of the sex of a person with an operatively reassigned gender by stating that tolerating 'such discrimination would be tantamount, as regards such a person, to a failure to respect the dignity and freedom to which he or she is entitled'. ${ }^{215}$

Admittedly, for certain fundamental rights the human dignity element will be naturally more obvious than in others, for example the right to life (Article 2 of the Charter), the right to liberty and security (Article 6), the right to marry (Article 9), the right to asylum (Article 18), non-discrimination (Article 21), equality between women and men (Article 23) and the integration of persons with disabilities (Article 26). ${ }^{216}$ For other rights, such as the right to vote (Article 40), the right to good administration

\footnotetext{
${ }^{209}$ Explanations to the Charter's Art. 1. Emphasis added.

${ }^{210}$ From this perspective, the Charter seems to closely follow the German theory which links essence (Wesensgehalt) very closely to human dignity; see Kokott, supra n. 32, p. 890, 892 who points out that, according to German doctrine, the essence protects the absolute core, which cannot be subjected to any restriction of a human dignity in a fundamental right. It therefore seems that we are facing an example of vertical cross-fertilisation which is all the more interesting because there seems to be no reception of this German reasoning in other countries; see Von Bernstorff, supra n. 12, p. $171-172$.

${ }^{211}$ A. Barak, Human Dignity. The Constitutional Value and the Constitutional Right (Cambridge University Press 2015).

${ }^{212}$ Ibid., Parts II and III.

${ }^{213}$ In Case C-36/02, Omega, ECLI:EU:C:2004:614, para. 34, the ECJ pointed out that the Community legal order undeniably strives to ensure respect for human dignity as a general principle of law'.

${ }^{214}$ It does, however, also not exclude the interference with dignity as a constitutional right.

${ }^{215}$ Case C-13/94, P v S and Cornwall County Council, ECLI:EU:C:1996:170, para. 22.

${ }^{216}$ This is obviously a non-exhaustive list. Jones points out three distinct areas where the value of human dignity is relevant, namely asylum, victims of crime and discrimination on grounds of sexual orientation; see J. Jones, 'Human Dignity in the EU Charter of Fundamental Rights and its Interpretation Before the European Court of Justice', 33 Liverpool Law Review (2012) p. 294.
} 
(Article 41) or the right to petition (Article 44), the human dignity element is allegedly less pronounced; there, the link with one of the other values of the EU enshrined in Article 2 TEU, is more apparent, for example freedom, democracy or the rule of law. When finding an interference with the essence of the fundamental right to effective judicial protection in Schrems, the European Court of Justice established a clear link between this fundamental right and the rule of law by emphasising that the 'existence of effective judicial review ... is inherent in the existence of the rule of law. ${ }^{217}$ To give another example involving freedom as a core societal value: if a communist regime closes down churches or other places of worship and its justification is that the freedom of religion can no longer be exercised, this would interfere with the essence of the freedom of religion and would consequently also impair freedom as societal value of the EU.

\section{Conclusion}

This article is an endeavour to search for a conceptualisation of essence: a search for its origins, a search for its meaning and a search for a methodological approach for determining interference with this concept. This search reveals that the concept of essence can be found in different layers of the multi-level system of protection of fundamental rights in Europe. Not only the Charter, but also the constitutions of the Member States as well as - through interpretation by the European Court of Human Rights - the ECHR, rely on this notion and use it in constitutional practice. This article argues that introduction of this notion to the EU legal system is a combination of sources on different layers which, through cross-fertilisation, have contributed to the protection of essence at the EU level. Even though the protection of essence, and the methodology for determining interference with the essence, differs somewhat throughout these layers, a certain degree of convergence can nonetheless be observed. The common feature of multi-layered essence protection is that this notion epitomises the untouchable core that should under no circumstances be restricted or interfered with. This multi-layered system, however, also reveals some divergence as to the methodology used to determine interference with the essence. In particular, the case law of the European Court of Human Rights partially uses proportionality as a method for determining an interference with the essence in cases such as Kart, ${ }^{218} \mathrm{Cudak}^{219}$ or Şahin. ${ }^{20}$ This article suggests that the EU should not follow this methodology since it leads to an overlap between

\footnotetext{
${ }^{217}$ Schrems, supra n. 4, para. 95.

${ }^{218}$ Kart $\mathrm{v}$ Turkey, supra $\mathrm{n} .187$.

${ }^{219}$ Cudak v Lithuania, supra n. 186.

${ }^{220}$ Leyla Şahin v Turkey, supra n. 190.
} 
particularly serious interferences and interferences with the essence of a fundamental right.

Coming back to the introduction of this article, equating the establishment of an interference with a fundamental right with peeling an onion - where the essence is the most-inner layer - the essence could be compared to the last bastille within a fundamental right which, if ruined, leads to the non-existence of this right. Taking the comparison with peeling an onion a bit further, all other types of interference with a fundamental right - from justified to an unjustified and particularly serious interference - have to be determined by means of proportionality balancing. In defining the concept of essence, European Court of Justice jurisprudence, notably in the field of privacy, plays a particularly important role and could be portrayed as the knife that peels the onion of fundamental rights to its innermost layer: the essence. However, it is important that a finding of interference with the essence does not become a shortcut for replacing the establishment of (ordinary) interferences with fundamental rights. Neither should essence be deployed as a matter of convenience because it avoids the deployment of the (sometimes difficult) proportionality balancing; it should, therefore, be reserved for particular and perhaps even rare cases where the core of a fundamental right is at stake. After all, one does not always peel an onion to its innermost layer. 